\title{
Az Európai Unió költségvetésének jövője a 2021-2027-es többéves pénzügyi keret tükrében
}

A tanulmány az Európai Unió közös költségvetésének bevételi és kiadási oldalát jellemző fö problémák vizsgálatán keresztül rámutat azokra a szempontokra, amelyek alapvetően befolyásolják a jövőbeli változtatási lehetőségek irányait és korlátait is. A szerző áttekinti a 2021 és 2027 közötti időszakra készülő többéves pénzügyi keretre vonatkozó bizottsági javaslatcsomagot, az abban körvonalazott elképzeléseket. Az elemzés felhívja a figyelmet a változások megfelelő összehasonlítási módszerének jelentőségére, ami a javasolt átrendeződés árnyaltabb értékelését teszi lehetővé. Az elemzés fö következtetése, hogy a nettó pozíciót mindenek fölé helyező szemlélet meghatározója marad a közös költségvetésről folyó vitáknak, mert az uniós költségvetés kiadásainak köszönhető „európai hozzáadott érték” jelentőségét a tagállamok továbbra sem veszik érdemben tudomásul. A kiadási oldalon pedig - a változatlanul szükös keretek ellenére - fokozatosan folytatódni fog a hagyományosan sok forrást felhasználó két szakpolitikára: a kohéziós és az agrárpolitikára fordított kiadások csökkentése, mert csak így lehetséges az új prioritások költségvetési támogatását előteremteni, illetve megerősíteni.* Journal of Economic Literature (JEL) kód: E61, F36.

Az integrációs folyamathoz kapcsolódó szakpolitikák megvalósításához, az egyes területeken meghatározott feladatok ellátásához értelemszerüen szükség van költségvetési forrásokra is, amelyeket részben az uniós szintű költségvetés keretében kell biztosítani. Bár az EU-tagállamok közötti viták során az Európai Unió közös költségvetésének ügye egyre fontosabbá vált, politikai jelentősége ellenére a költségvetés igen szerény nagyságrendü: kiadásai a gyakorlatban az EU bruttó nemzeti jövedelmének (GNI) 1 százalékát teszik ki, miközben az egyes tagállamok nemzeti költségvetései a GNI 35-65 százalékát osztják újra. Ha a tagállamoknak közös érdekeken alapuló stratégiai céljaik vannak, akkor ezek támogatásához megfelelő nagyságú közös költségvetést kellene rendelniük. El kellene dönteniük, hogy milyen uniót akarnak, melyek a prioritásaik, és ezek tükrében milyen uniós szintű kiadásokra lenne szükség.

Kengyel Ákos egyetemi tanár, Jean Monnet Chair, Budapesti Corvinus Egyetem Nemzetközi Tanulmányok Intézete (e-mail: akos.kengyel@uni-corvinus.hu). 
Az elmúlt évtizedek során nem tisztázódott egyértelműen, hogy melyek a közös költségvetés legfontosabb céljai. Az Európai Unió működéséről szóló szerződés (EUMSZ) 310-325. cikkei rögzítik a költségvetés müködésére vonatkozó elveket, a saját források szükségességét, valamint részletesen szabályozzák a közös költségvetés elkészítésének, elfogadásának és végrehajtásának intézményi, döntéshozatali folyamatát. Ugyanakkor korántsem beszélhetünk a tagállamok és az uniós szint között kialakított, világosan körülhatárolt, föderatív jellegű munkamegosztásról.

Az EU szintjén a jelentősebb költségvetési forrásokat igénylö kormányzati funkciók közül viszonylag kevés valósul meg (Begg [2009], Figueria [2009], Kengyel [2003], [2007]). Mivel az EU költségvetési kiadásainak meghatározó részét, körülbelül 70 százalékát az agrárpolitikával és a regionális politikával összefüggő kiadások képezik, megállapítható, hogy az uniós költségvetés elsősorban allokációs és disztribúciós feladatokat lát el. A regionális politika esetében erős a fejlesztési funkció is. Ugyanakkor az újraelosztási politika legtöbb területe érintetlen marad: így többek között az EU költségvetése nem foglalkozik jóléti transzferekkel (például munkanélküli-segélyekkel), egészségügyi biztosítással vagy például olyan közjavakkal, mint a védelem. Számos uniós szakpolitika finanszírozása kapcsán fellelhető azonban az európai közjavak biztosításának funkciója is.

A gazdasági stabilizáló szerep - a monetáris politika kivételével - szinte kizárólag a tagállami kormányok hatáskörében van, de bizonyos szempontból (elsősorban a kohéziós politikai transzfereknek köszönhetően) az EU költségvetésének is van stabilizációs szerepe. Emellett az is igaz, hogy a közös költségvetés finanszírozása kapcsán a tagállamok GNI-alapú befizetésének összege az azonos befizetési kulcs miatt a gazdasági teljesítménytől függően alakul, tehát van egyfajta automatizmus. Természetesen az EU költségvetése már csak méretéből adódóan sem képes makrogazdasági stabilizációs funkciót betölteni. Pedig az európai gazdaság kiegyensúlyozott és dinamikusabb fejlődése érdekében szükség lenne hathatósabb stabilizációs funkcióra. Ehhez az uniós költségvetési politikai hatáskörök és kapacitás erősítésére lenne szükség (Enderlein [2016], Hübner [2017]). Bár a válság nyomán elszaladó államadósságok kezelése elkerülhetetlenné tette az uniós szintü gazdaságpolitikai kormányzás kereteinek megerősítését (Juncker [2015]) - aminek során valóban komoly lépések történtek a kiszámíthatóbb nemzeti költségvetések kialakításának befolyásolására -, nem sikerült lényegi haladást elérni az uniós szintü költségvetés finanszírozásának és kiadási oldalának újragondolása terén. ${ }^{1}$

\footnotetext{
${ }^{1}$ A tagállamok hozzáállása alapján még az európai gazdasági kormányzás kereteinek reformja ellenére sem látszik reálisnak az, hogy a stabilizációs funkciót - akár csak az aszimmetrikus sokkok esetében - az Unió közös költségvetésén keresztül kívánnák komolyabb eszközökkel finanszírozni. A gazdasági kormányzás keretében létrehozták ugyan az európai stabilitási mechanizmust, elfogadták a „,hatos csomagot”, bevezették az európai szemesztert, megszületett a költségvetési paktum, elindult a bankunió megvalósítása, létrejött az európai bankfelügyelet - de a közös költségvetésben nem történtek változások. (Bár több fórumon is újra meg újra felvetik az euróövezet önálló költségvetése létrehozásának lehetőségét, ami már mind a bevételi, mind a kiadási tételek szempontjából alkalmas lenne a stabilizációs funkció betöltésére.)
} 


\section{A valódi saját bevételek hiánya és a lehetséges új források}

Az EUMSZ 311. cikke leszögezi, hogy az uniós költségvetést teljes egészében saját forrásokból kell finanszírozni, e forrásokat azonban tételesen nem sorolja fel. A napjainkra kialakult helyzet azt mutatja, hogy a valóban független saját források rendszerét - a vámbevételeken kívül - nem sikerült kialakítani. Pedig a valódi saját források, amelyek egyfajta finanszírozási autonómiát adnának az Európai Uniónak, alapvető fontosságúak lennének a közös költségvetés megfelelő működéséhez. Ezek hiánya, illetve elégtelen nagysága esetében ugyanis a közös költségvetés szinte teljes mértékben a tagállamok mindenkori akaratától, „fizetési hajlandóságától" függ.

A vámok (az úgynevezett hagyományos saját források) az EU költségvetésének továbbra is bevételi forrását képezik, részarányuk azonban napjainkra a közös költségvetés bevételeinek 16 százalékára csökkent. A második „saját forrás”, a hozzáadottértékadó-alapú hozzájárulás viszont már a nemzeti költségvetésekből érkezik. (Igaz, a vámbevételeket is a tagállamok hatóságai szedik be.) A hozzáadottértékadóalapú befizetés jelenleg körülbelül 12 százalékát éri el a közös költségvetés bevételeinek. Ezek mellett az eredetileg „,egyenlegező tételként” bevezetett - vagyis az előbbi bevételi forrásokon felül szükséges forrásigény fedezésére szolgáló - GNI-alapú hozzájárulás mértéke valamennyi tagállam esetében azonos arányú. Napjainkban a GNI-alapú forrás a közös költségvetés bevételeinek 72 százalékát teszi ki. A közös költségvetésnek néhány további saját bevételi forrása is van; ezek az összes forrás körülbelül 1 százalékát érik el. Ilyenek az uniós alkalmazottak jövedelemadó-befizetései, egyes EU-n kívüli országok uniós programokhoz való hozzájárulásai, valamint a versenypolitika kapcsán a vállalatokra kiszabott bírságok (EC [2018a]).

A saját források rendszeréhez kapcsolódik a brit visszatérítés sajátos mechanizmusának szabályozása is. A brit visszatérítést GNI-arányosan a többi tagállam fedezi, e tételből azonban a költségvetés fö nettó befizetői kedvezményt kapnak, az így fennmaradó összeget pedig a többi tagállamnak kell magára vállalnia. Tehát Ausztria, Németország, Hollandia és Svédország a „visszatérítéshez kapcsolódó kedvezményben" részesül. Ezen túlmenően más korrekciókat is bevezettek. Például további csökkentésekben részesültek egyes olyan tagállamok, amelyek költségvetési terhei „túlzottnak” minősültek. A 2014-2020-as költségvetési időszakban például Németország, Hollandia és Svédország esetében csökkentették a hozzáadottértékadó-alapú befizetés lehívási kulcsát. Ausztria, Hollandia, Svédország és Dánia emellett még a GNI-alapú hozzájárulás tekintetében is egyöszszegü csökkentésben részesül.

Az Egyesült Királyság EU-ból való kilépése lehetőséget teremt a visszatérítések és a visszatérítéshez kapcsolódó kedvezmények bonyolult rendszerének megszüntetésére (Haas-Rubio [2017]). Annak elkerülésére, hogy egyes tagállamok hozzájárulásai 2021-től hirtelen jelentős mértékben megemelkedjenek, a Bizottság azt javasolja, hogy a tagállamok a GNI-alapú hozzájárulásaikra egyösszegü kedvezményben részesüljenek; a kedvezményt öt éven át fokozatosan kivezetnék, majd 2026-ra teljesen megszüntetnék. 
A kialakult helyzet összefoglalva megállapíthatjuk, hogy a hagyományos saját forrásokból származó bevételek fokozatos térvesztése és az elmúlt költségvetési időszakok során végbement arányeltolódás következtében az EU költségvetésének bevételei egyre inkább a GNI-arányos hozzájárulásokból származnak. Ez a folyamat aláássa a saját forrásokra épülő költségvetési gazdálkodás elvét és az EU finanszírozási autonómiáját, hiszen lényegében csak a vámbevételek az EU költségvetésének valódi saját forrásai. A hozzáadottértékadó-alapú forrás és a GNI-alapú hozzájárulás már a tagállami költségvetésekhez kötődik, ezáltal az uniós költségvetés - ez utóbbi két tételt összeadva - gyakorlatilag legalább 85 százalékban a tagállamok befizetési hajlandóságától függ, vagyis nem beszélhetünk valóban autonóm költségvetési gazdálkodásról.

Mindez azt jelenti, hogy az EU közös költségvetését meghatározóan a tagállamok közvetlen transzferei finanszírozzák. Ebből adódóan a közös költségvetés egésze kapcsán a nettó egyenleg alakulása vált meghatározó szemponttá a tagállamok számára, aminek egyenes következménye, hogy nem mutatnak semmi hajlandóságot a források növelésére. Mivel a közös költségvetés forrásainak döntő hányadát a tagállamok „átutalásai” biztosítják, nem meglepő, hogy a nettó egyenlegük alakulása kitüntetett figyelmet kap. Éppen ezért lenne szükséges olyan új, valóban saját forrásokat bevezetni, amelyek függetlenek a tagállamoktól (Rubio [2011], Cipriani [2014], Fuest és szerzötársai [2015]). Bár már számos javaslat született, 1988 óta nem sikerült újabb közös bevételi forrásokról megegyezni.

Az elmúlt évtizedek során készült bizottsági és szakértői elemzésekben számtalan javaslat született a szóba jöhető új saját forrásokról (Monti [2017], Núñez-Ferrer és szerzőtársai [2016], Haug és szerzőtársai [2011]). Többek között az alábbi saját források bevezetésének lehetősége merült fel javaslatként:

- átalakított hozzáadottérték-adó,

- szén-dioxid-adó vagy az Európai Unió kibocsátáskereskedelmi rendszerének árveréseiből származó bevétel,

- fosszilis üzemanyagokra kivetett adó (vagy ennek korlátozottabb formája, amely csak a közúti szállítmányozásra vonatkozna),

- villamosenergia-adó,

- társasági jövedelemadó,

- pénzügyi tranzakciós adó,

- seigniorage,

- légi közlekedéssel összefüggő díj (a repülőút hossza vagy a járatok száma alapján),

- kerozinadó,

- pénzügyi intézmények nyereségére kivetett adó.

\footnotetext{
${ }^{2}$ A kialakult helyzet a költségvetési viták intézményi problémáira is rávilágít, ugyanis a költségvetésről a döntő szót a tagállamok mondják ki az Európai Tanácsban. A költségvetési alkukban az Európai Bizottság és az Európai Parlament érdekérvényesítő képessége viszonylag korlátozott, pedig az uniós szintű érdekeket ezek az intézmények tudnák megjeleníteni. Ugyanakkor az Európai Parlament szerepe is erős, hiszen a költségvetést nélküle nem lehet elfogadni (Heinemann és szerzőtársai [2010]).
} 
A szóba jöhető saját források megfelelőségét különböző szempontok szerint értékelhetjük. Ilyen lehet például a forrás kiszámításának egyszerüsége és átláthatósága, a méltányos tehermegoszlás, a bevétel elégséges nagysága és stabilitása, esetleg az európai szintű hozzáadott érték alapján való indokoltsága. Az új forráshoz kapcsolódóan lényeges szempont az is, hogy a javasolt bevételi forrás kapcsolódjon valamilyen uniós szakpolitikához, illetve stratégiai célok megvalósításához. ${ }^{3}$ Összességében megállapítható, hogy nem létezik minden kritériumnak tökéletesen megfelelő saját forrás, így elvileg bármelyik felmerülö új saját forrást vezetnék is be, bizonyos elvárásokról le kellene mondani. Részben ebből is adódik a különféle elemzéseknek az a közös jellemzője, hogy több új saját forrás egyidejü bevezetésével kívánnának egy összességében elfogadható rendszert megalkotni.

A reformok megalapozására 2014 februárjában Mario Monti, az Európai Bizottság korábbi tagjának vezetésével egy magas szintű szakértői csoportot hoztak létre, amelynek 2016 végéig kellett elkészítenie a saját források reformjára vonatkozó javaslatát (Monti [2017]). A szakértői jelentés ajánlásait megfontolva a 2021 és 2027 közötti időszakra vonatkozó bizottsági javaslatcsomag a hagyományos saját források, az egyszerűsített módon kiszámított hozzáadottértékadó-alapú hozzájárulás és a GNIalapú forrás mellett három új saját forrás bevezetését javasolja. Emellett a vámok beszedési költségeinek fedezésére a tagállamok által jelenleg visszatartott 20 százalékos részarány 2021-től 10 százalékra csökkenne, a hozzáadottértékadó-alapra számított 0,3 százalékos befizetési kulcs pedig 1 százalékra emelkedne (EB [2018c]).

A három új saját forrás a következő lenne:

- a közös konszolidált társaságiadó-alapból származó forrás (3 százalékos lehívási kulccsal),

- az európai kibocsátáskereskedelmi rendszer árverési bevételeinek 20 százaléka,

- az újrafeldolgozatlan műanyag csomagolási hulladék mennyisége alapján kiszámított nemzeti hozzájárulás ( 0,8 euró/kilogramm).

A javasolt új források a közös költségvetés bevételeinek körülbelül 12 százalékát tennék ki. Tehát továbbra is fennmaradna a GNI-alapú befizetésektől való nagymértékü függőség, ugyanakkor valóban el lehetne indulni a valódi saját források megteremtése felé. A Bizottság számításai szerint az EU költségvetésének bevételi oldalán a hagyományos saját források részaránya a 2018-as 15,9 százalékról 15,1-re csökkenne 2027ben. A hozzáadottértékadó-alapú befizetés részesedése a 2018. évi 12 százalékról 14,1-re változna. A GNI-alapú befizetés a 2018-as 72,1 százalékos részarányról 56,8re mérséklödne 2027-re (1. és 2. ábra).

Még nem tudhatjuk, hogy mi lesz a bizottsági javaslatban felvetett források sorsa, ugyanis az elfogadásukhoz a tagállamok egyhangú döntésére lenne szükség. Új bevételi források bevezetésére irányuló komoly szándékot azonban továbbra sem lehet érzékelni a tagállamok részéről. Ennek legfőbb magyarázata, hogy

\footnotetext{
${ }^{3}$ Kiemelkedő jelentőségű ezen a téren az Európai Unió éghajlat-, energia- és környezetvédelmi politikájához és a fenntartható fejlődéshez kapcsolódó lehetséges források elemzése. Nem véletlenül kap nagy figyelmet a szén-dioxid-kibocsátáshoz kapcsolódó saját forrás vizsgálata (Le Cacheux-Laurent [2009], Schratzenstaller [2018]).
} 
1. ábra

A saját források részaránya, 2018 (százalék)

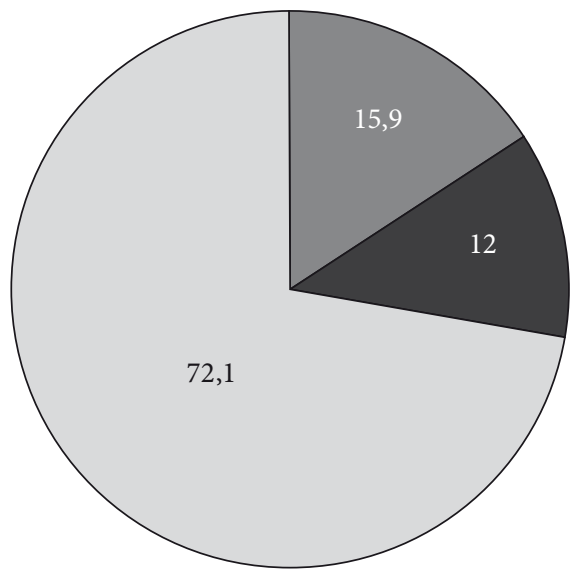

Hagyományos saját források

Hozzáadottértékadó-alapú hozzájárulás

GNI-alapú hozzájárulás

Forrás: EC [2018a].

2. ábra

A saját források becsült részaránya, 2027 (százalék)

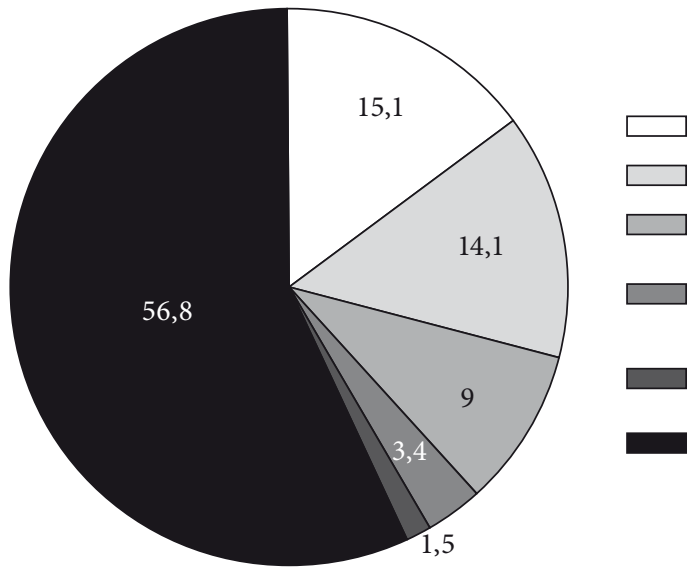

Hagyományos saját források

Hozzáadottértékadó-alapú hozzájárulás

Társaságiadó-alapú hozzájárulás

Nem újrahasznosított műanyag hulladék utáni befizetés

Kibocsátáskereskedelmi rendszer alapján számított hozzájárulás

GNI-alapú hozzájárulás

Forrás: EC [2018a].

a tagállamok a GNI-alapú befizetés meghatározó súlyát láthatóan jónak tartják, mivel ez igazságosnak tekinthető, arányos teherviselést biztosít, és mindig stabilan rendelkezésre áll. Kétségtelen, hogy bármilyen új, uniós szintű saját forrás számos bizonytalanságot vetne fel (például a rendelkezésre állást, a kiszámíthatóságot vagy az arányos teherviselést illetően).

Mindezek tükrében levonható az a következtetés, hogy a tagállami költségvetésekből származó befizetésektől való függés még hosszú ideig jellemezni fogja az EU költségvetésének finanszírozását. A tagállamok emiatt a jövőben sem lesznek érdekeltek a közös költségvetés érdemi növelésében. Ez a hozzáállás pedig a kiadási oldal reformját is nagymértékben megnehezíti. 


\section{A kiadási oldalt jellemző problémák}

1988 óta - az éves költségvetések mellett, azok megalapozására - az EU középtávú költségvetési terveket is készít, amelyek több évre szóló kiadási előirányzatokat tartalmaznak. Ez nagyfokú stabilitást biztosít az egyes kiadási tételek finanszírozásában, a több évre szóló programok támogatásának garantálásában. Így az éves költségvetési viták már a keretköltségvetésben meghatározott sarokszámok keretein belül folynak. A 2014 és 2020 közötti időszaktól kezdődően a keretköltségvetés elnevezése többéves pénzügyi keret (Multiannual Financial Framework, MFF). Korábban, az első Delorscsomag (1988-1992), a második Delors-csomag (1993-1999), majd az Agenda 2000 (2000-2006) idején „pénzügyi perspektíva” névvel illették a többéves keretköltségvetést, és így volt ez a 2007-2013-as időszakban is. ${ }^{4}$

Az 1988 és 1992 közötti időszakról az 1993-1999-es időszakra a költségvetés rendelkezésére álló források évi maximális plafonja az EU-tagállamok összesített bruttó nemzeti termékének (GNP) 1,18 százalékáról 1,23 százalékára emelkedett. A 2000-től 2006-ig tartó időszakban a plafon a GNP 1,27, illetve a GNI 1,24 százaléka volt, ami változatlan maradt a 2007-2013-as időszakban is, majd a plafon 2014 és 2020 között 1,23 százalék lett, a 2021 és 2027 közötti időszakban pedig - az Európai Bizottság javaslata szerint - a britek nélkül számított EU27 bruttó nemzeti jövedelmének 1,29 százalékára nőne. A tényleges kiadások szintje 1988-tól 1999-ig fokozatosan emelkedett a GNP 1,15 százalékáról 1,22 százalékára. A 2000-2006-os időszakban már csak 1,07 százalékot ért el, majd a nagy nettó befizető tagországok határozott ellenállása következtében a 2007 és 2013 közötti időszakban 1,0, 2014 és 2020 között pedig 0,95 százalékra csökkent a kifizetések GNI-hez viszonyított aránya. 2021-től a britek nélkül számított uniós GNI arányában - ugyancsak az Európai Bizottság javaslata szerint - 1,08 százalékot érne el. Ugyanakkor a kifizetések éves összege (folyó áron) folyamatosan nőtt: az 1988 és 1992 közötti 47 milliárd ecuről az 1993-1999-es időszakra 72 milliárd ecu-re, a 2000-2006-os időszakban 92 milliárd euróra, 2007 és 2013 között 117 milliárd euróra, 2014 és 2020 között pedig 130 milliárd euróra. A Bizottság tervezete alapján a kifizetések évi átlaga 2021 és 2027 között 158 milliárd eurót tenne ki (1. táblázat).

Visszatekintve a közös költségvetés kiadási oldalán bekövetkezett változások történetére, az egyes kiadási tételek közötti arányok lassú, fokozatos elmozdulása

\footnotetext{
${ }^{4}$ 2009-et megelőzően nem volt szerződéses alapja a többéves pénzügyi keret készítésének az EU úgynevezett elsődleges jogában, ezért annak elfogadását mindig úgynevezett intézményközi megállapodással szentesítették (az Európai Parlament, az Európai Unió Tanácsa és az Európai Bizottság állapodott meg egymással). A lisszaboni szerződésként is ismert EUMSZ-be viszont már bekerült a többéves pénzügyi keret elkészítésének feladata (312. cikk). A keret hosszát a szerződés nem rögzíti, csak azt határozza meg, hogy a költségvetési keretet legalább ötéves időszakra kell kidolgozni. Az elmúlt évtizedek során a tagállamok és az Európai Bizottság is annyira megszokták, hogy hét évre tervezzék meg az Európai Unió hosszú távú költségvetését, hogy a keret hosszára vonatkozó érdemi tárgyalásokra mind ez idáig nem került sor. Pedig az Európai Parlament számtalanszor kezdeményezte már a többéves pénzügyi keret időtartamának felülvizsgálatát, felvetve az öt-, hét- és a tíz- (öt + öt) éves kerettervek lehetséges előnyeit és hátrányait a kiszámíthatóság, a rugalmasság és a többéves programok megvalósításának szempontjából. (A többéves pénzügyi kerettervek időtartamára vonatkozó lehetséges forgatókönyvek elemzését lásd Kengyel [2017], [2018].)
} 


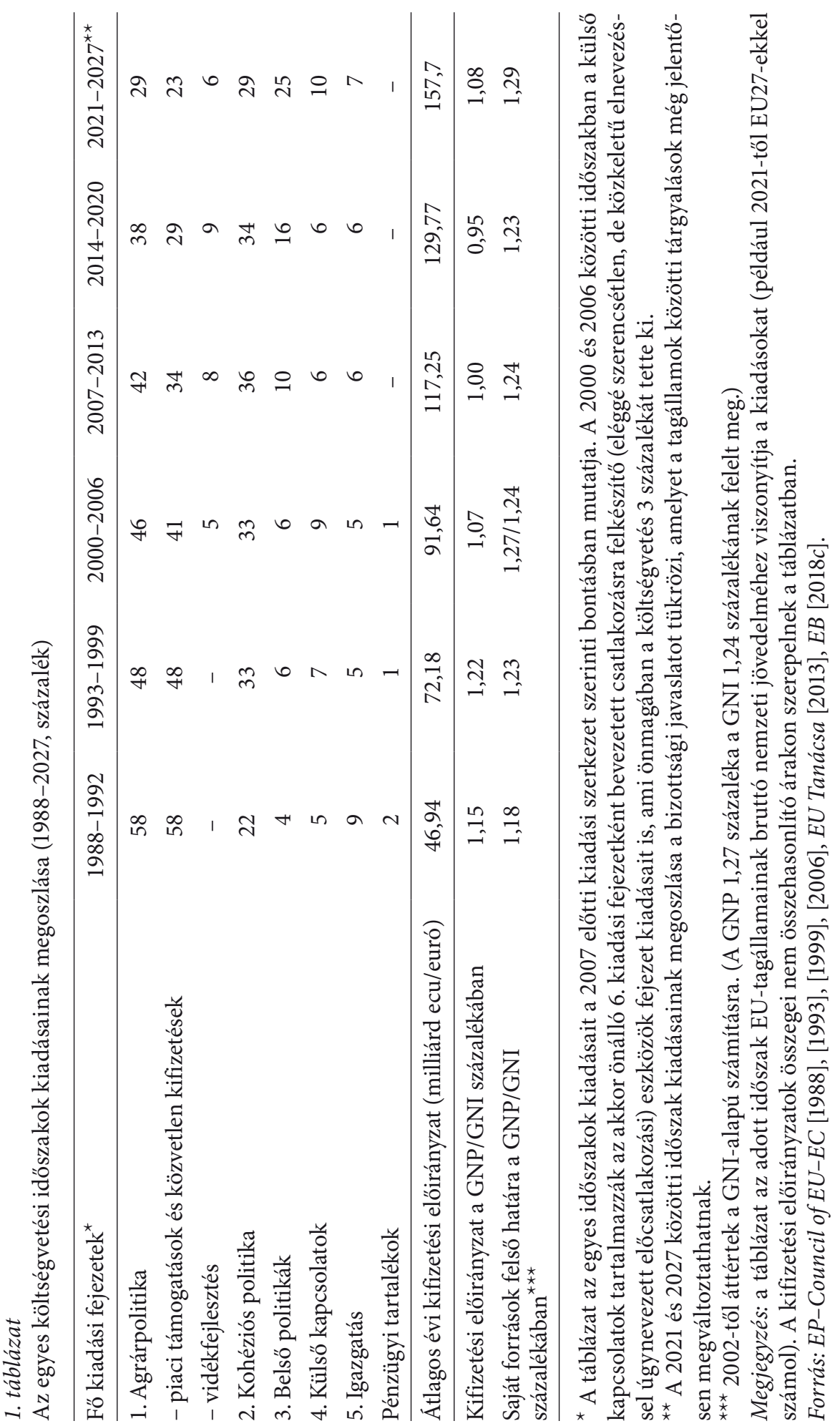


figyelhető meg. Az integráció mélyülésével és a taglétszám növekedésével párhuzamosan az EU költségvetése is megváltozott. Eleinte a kiadások nagy részét a közös agrárpolitika finanszírozására fordították. Majd egyre jobban előtérbe került a tagállamok közötti kohézió erősítésének igénye: az 1980-as évek végétől megerősödött az úgynevezett strukturális - lényegében fejlesztési vagy felzárkóztatási - alapok szerepe. A többi közös szakpolitika finanszírozási háttere azonban továbbra is szinte elenyésző maradt.

A két meghatározó szakpolitika az egyes költségvetési időszakokban szinte változatlanul az összes kiadás 75-80 százalékában részesült. Ez a meghatározó részarány még a 2014 és 2020 közötti időszakban is fennmaradt: e két szakpolitikára a kiadások 72 százalékát fordítják. Meghatározó súlyuk 2021-től is fennmarad, de részarányuk a bizottsági javaslat szerint számottevően (összesen akár 60 százalék alá) csökkenne. Természetesen eközben számos tartalmi, megközelítésbeli hangsúlyeltolódás következett be e két terület szabályozásában is. Általában jellemző, hogy a többi szakpolitikának jutó támogatás csak ennek a két területnek a rovására növekedhet, hiszen a költségvetési keret nagysága GNI-arányosan érdemben nem változik.

Meg kell jegyeznünk, hogy mivel a két hagyományosan meghatározó szakpolitika tagállamoknak juttatott kiadásokat tartalmaz, a biztos források előnyben részesítése miatt az országok többsége kiáll ezek fenntartásáért - ahelyett, hogy a bizonytalan, minden tagállam számára rendelkezésre álló keretekért folyó versenyben venne részt nagyobb mértékben (például a $\mathrm{K}+\mathrm{F}$-re, oktatási programokra vagy a transzeurópai hálózatokra szánt források esetében). Emellett az is tény, hogy napjainkban az EU költségvetési kiadásainak négyötöde előre meghatározott célokra le van kötve, így nagyon nehéz a többéves pénzügyi időszak során felmerült új kihívásokra megfelelően reagálni. ${ }^{5}$

\section{A nettó egyenleg kitüntetett szerepe}

Általában jellemző a többéves pénzügyi kerettervről szóló tárgyalásokra, hogy mindegyik tagállam kap valamit, de igazi áttörés nem következik be: hosszú távú reformok helyett a korábban kialakult rendszert csak kisebb kiigazításokkal változtatják meg. Bár a döntést megalapozó bizottsági anyagok sokszor használják a reform kifejezést, és próbálnak is bizonyos területeken jelentősebb elmozdulást elérni, mégis inkább mindenki a kialakult status quo megörzésére törekszik a tagállamok közötti tárgyalások során. Az egyes tagállamok által képviselt érdekeket jellemzően a nettó befizetői, avagy a nettó haszonélvezői pozíció határozza meg. Ezek alapján a nettó befizetők minden vita során az uniós szintű kiadások kapcsán a hatékonyságot és az uniós hozzáadott érték bizonyítását szeretik számonkérni - ezáltal támasztva alá azt az álláspontjukat, hogy nincs szükség nagyobb költségvetési kiadásokra,

\footnotetext{
${ }^{5}$ Ezt a célt elvileg a félidős felülvizsgálat szolgálja, ugyanakkor a 2014 és 2020 közötti időszak példája is jól mutatta, hogy a felülvizsgálat során javasolt összes változtatás sem eredményezett arányeltolódást az egyes kiadási fejezetek között (EC [2016]).
} 
illetve a felmerülő új prioritások a meglévő kereten belüli átrendezéssel is finanszírozhatók. A nettó haszonélvezők viszont a két fő támogatási forrást felhasználó szakpolitika fenntartásának szükségessége mellett érvelnek. A jellemző tagállami érdekcsoportokat mutatja a 3. ábra.

3. ábra

Jellemző tagállami érdekcsoportok a költségvetési vitákban

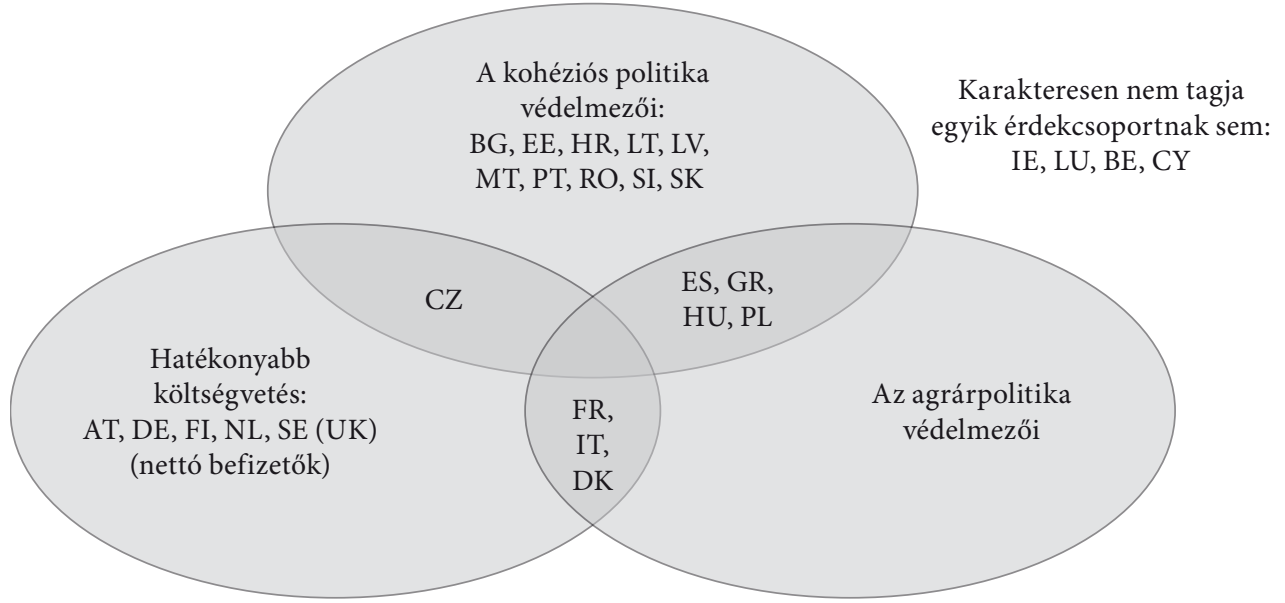

Röviditések: AT: Ausztria, BE: Belgium, BG: Bulgária, CY: Ciprus, CZ: Cseh Köztársaság, DE: Németország, DK: Dánia, EE: Észtország, ES: Spanyolország, FI: Finnország, FR: Franciaország, GR: Görögország, HR: Horvátország, HU: Magyarország, IE: Írország, IT: Olaszország, LT: Litvánia, LU: Luxemburg, LV: Lettország, MT: Málta, NL: Hollandia, PL: Lengyelország, PT: Portugália, RO: Románia, SE: Svédország, SI: Szlovénia, SK: Szlovákia, UK: Egyesült Királyság.

Forrás: saját szerkesztés.

A nettó pozíció igazságos meghatározása viszont több szempontból koncepcionális nehézségekbe ütközik, mivel különböző módszertani problémák merülnek fel a költségvetés mindkét oldalának elemzésével kapcsolatban. Az adatok többféleképpen prezentálhatók, és ez gyakran zavaró tényező lehet. A németek - nem alaptalanul a bruttó transzfereket hangsúlyozzák, a spanyolok az egy főre jutó nyereségre hívják fel a figyelmet, miközben a britek azt szerették hangoztatni, hogy milyen keveset kapnak az uniós átlaghoz képest. A GDP, a lakosság és a költségvetési részesedés mind lehetséges viszonyítási alapok a különböző összehasonlításokban. Kérdés az is, hogy nominális árfolyamon vagy vásárlóerő-paritáson végezzük-e el a számítást. Röviden összegezve azt mondhatjuk, hogy a különböző számítások alapján nagyon sokféle egyenlőtlenség mutatható ki. Kétségtelen, hogy a költségvetési egyensúlytalanságok meghatározója a kiadási oldal (mindenekelőtt a közös agrárpolitikára és a regionális politikára fordított kiadások alakulásával összefüggően), ugyanakkor a befizetéseknél is felmerülnek torzító tényezők.

A saját források esetében ilyen torzító körülmény például a vámbefizetésekkel összefüggésben az, hogy az áru Európai Unió területére való belépése helyén szedik 
be a vámokat, ezért például Hollandia igen jelentős (a GNI-részarányához képest mintegy háromszoros) befizetőnek tünik ezen a területen. ${ }^{6}$ A kiadások kapcsán pedig mérlegelésre adhat okot az olyan tételek megítélése, amikor nem valamely tagállamnak juttatott támogatásokról van szó, mégis közvetetten adott országok részesülnek a kiadásokból. Például - bár van benne logika - az EU hivatali szervezetének müködtetésére fordított kiadásokat eléggé aggályos lenne a két fő haszonélvező ország (Belgium és Luxemburg) részesedéseként értékelni.

Mindezen bizonytalanságok mellett is kétségtelen, hogy tartósan fennálló különbségek alakultak ki a közös költségvetésbe való nettó befizetések terén. Hosszú időn át Németország és az Egyesült Királyság voltak a nagy nettó befizetők, amelyeket később néhány újabb ország követett. Az Egyesült Királyság helyzete a visszatérítési mechanizmus bevezetésével vált kedvezőbbé. Kétségtelen, hogy a költségvetés finanszírozásában jelenleg hat tagállam (Németország, Svédország, Belgium, Hollandia, Dánia és Franciaország) vállalja a legnagyobb terheket. A kevésbé fejlett tagállamok (Görögország, Portugália, Spanyolország és az új tagok) jelentős nettó haszonélvezői pozíciója igazolhatónak tünik, hiszen ezek az országok a kohéziós politika (és az agrártámogatások) fő kedvezményezettjei.

A nettó pozíció alakulásának számszerüsítése kapcsán lényeges tanulságokkal szolgálnak a 2007 és 2013 közötti időszakra vonatkozó végleges, illetve a 2014-2020-as ciklusra vonatkozóan eddig rendelkezésre álló adatok (4. ábra).

A 4. ábra alapján látható, hogy a vizsgált időszakokban a fő nettó befizetők pozíciója a tagállami bruttó nemzeti jövedelem 0,21-0,41 százaléka közötti sávban mozgott, miközben a föbb nettó kedvezményezettek a GNI-jük 3-4 százalékát elérö - sőt egyes esetekben meg is haladó - nettó transzferben részesültek. Mindez azt jelenti, hogy viszonylag jelentős újraelosztásra kerül sor úgy, hogy a nettó befizetőknek ez nem jelent igazán komoly tehervállalást. ${ }^{7}$ Ugyanakkor - ahogy ezt már számos elemzés kimutatta - a belső piacból származó kereskedelemteremtés legfőbb nyertesei éppen ezek a fejlettebb tagállamok. Tehát az integrációból származó „nyereségek” és „,veszteségek” körét semmiképpen sem szabad a közös költségvetéssel szemben kialakult egyenleggel azonosítani.

Az uniós költségvetés jelentőségét sajnos alábecsülik a tagállamok, mivel hozzáállásuk és politikai nyilatkozataik alapján úgy tünhet, mintha nulla összegü játékról

\footnotetext{
${ }^{6}$ A jól ismert magyarázat az, hogy a holland kikötők a legfontosabb belépési pontok az EU-n kívüli termékek számára. Ez a „rotterdami hatás” azt eredményezi, hogy a holland befizetésnek tartott hozzájárulás jelentős részét a gyakorlatban más tagállamok fogyasztói fizetik meg. Ez a hatás értelemszerüen mindegyik külső határ mentén lévő, illetve nagy áruszállító repülőgép-forgalommal rendelkező tagállam esetében fennáll valamilyen mértékben.

Abszolút összegekben az uniós költségvetéssel szembeni egyenlegek alakulására vonatkozóan rendelkezésre álló legfrissebb adatok szerint a 2014-2016-os időszakban az uniós költségvetés öt legfőbb haszonélvezőjének és öt legfőbb finanszírozójának egyenlege a következőképpen alakult: a lengyel évi 10,1 milliárd, a román 5,2 milliárd, a görög 4,8 milliárd, a magyar 4,6 milliárd és a cseh 4 milliárd eurós nettó transzfer áll szemben a német 13,6 milliárd, a brit 7,6 milliárd, a francia 7,4 milliárd, az olasz 3,5 milliárd és a holland 2,8 milliárd eurós nettó befizetéssel (EC [2018b]). A kedvezményezett országok adatainak értékelésekor figyelembe kell venni, hogy ezekben az években fizették ki a 2007-2013-as időszakra vonatkozó utolsó számlákat.
} 
4. ábra

Tagállami nettó egyenlegek 2007-2013 és 2014-2017 között (évi átlag a GNI százalékában)

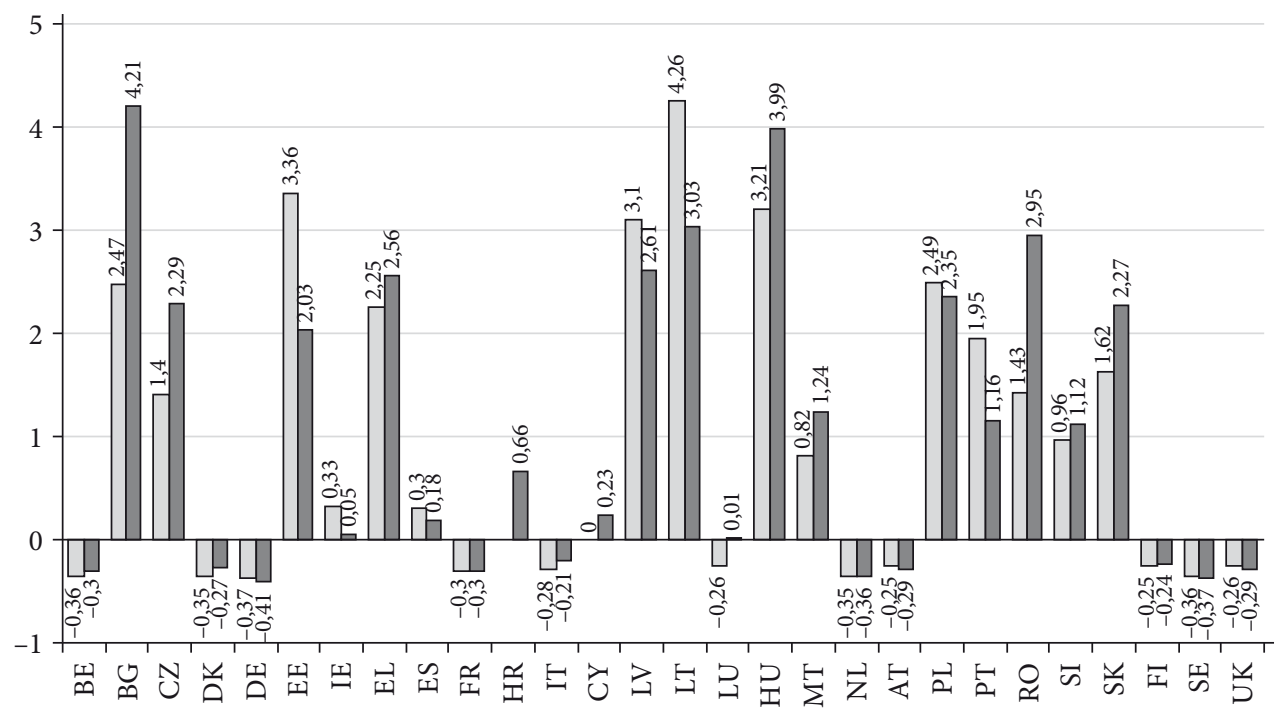

Nettó egyenleg, 2007-2013

Nettó egyenleg, 2014-2017

Röviditések: AT: Ausztria, BE: Belgium, BG: Bulgária, CY: Ciprus, CZ: Cseh Köztársaság, DE: Németország, DK: Dánia, EE: Észtország, EL: Görögország, ES: Spanyolország, FI: Finnország, FR: Franciaország, HR: Horvátország, HU: Magyarország, IE: Írország, IT: Olaszország, LT: Litvánia, LU: Luxemburg, LV: Lettország, MT: Málta, NL: Hollandia, PL: Lengyelország, PT: Portugália, RO: Románia, SE: Svédország, SI: Szlovénia, SK: Szlovákia, UK: Egyesült Királyság. Forrás: EC [2014], [2019], évi nettó egyenlegek alapján saját számítás.

lenne szó. Pedig az európai szintű hozzáadott értéknek köszönhetően az uniós költségvetési támogatásokból számos kölcsönös előny származik (Gros-Micossi [2005], Rubio [2011], Monti [2017]). Ilyen általános előnyökként értelmezhetők:

- a határokon átnyúló, közvetett keresleti és kínálati hatások;

- a közös fellépésből adódó szinergiák és méretgazdaságossági előnyök;

- az uniós támogatások és pénzügyi eszközök katalizátorszerepe, számottevő multiplikátorhatásuk. ${ }^{8}$

A Bizottság a 2021 és 2027 közötti költségvetési keretre tett javaslatában is hangsúlyozza a költségvetés „uniós hozzáadott értékének” a jelentőségét, amelyen olyan területek támogatását érti, ahol az unió költségvetése nagyobb hatást képes kiváltani, mint amennyire a nemzeti szintü közfinanszírozás képes lenne, illetve az erőforrások együttes mozgósításával olyan eredményeket lehet elérni, amelyekre a tagállamok egyedül nem képesek (EB [2018a]).

${ }^{8}$ A közös költségvetésen keresztül nyújtott vissza nem térítendő támogatási formák mellett a pénzügyi eszközök alkalmazására jó például szolgál az Európai Beruházási Bank és az Európai Bizottság által müködtetett, az úgynevezett Juncker-terv megvalósítását szolgáló Európai Stratégiai Beruházási Alap (EFSI), amely 15-17-szeres áttéttel (multiplikátorral) fejti ki hatását. 
Azt is fontos kiemelni, hogy számos uniós szinten finanszírozott szakpolitika esetében nem lehet egyértelmüen meghatározni a támogatások haszonélvezőinek körét. Erre többek között jó példaként szolgál:

- az Erasmus+ program, amelynek keretében a küldő és a fogadó országok is nyertesei az oktatási mobilitási együttműködésnek,

- a K + F-et támogató uniós szintü keretprogram (jelenleg a Horizont 2020), amelynek keretében a támogatásoknak határokon átnyúló (spill over) hatásai vannak,

- a kohéziós politikai támogatásokból származó kölcsönös előnyök, hiszen a fejlett tagállamok megrendelések formájában és a projektek megvalósítása során közvetlen és közvetett módon részesülnek a támogatások hatásaiból,

- a bel- és igazságügyi együttmüködés keretében támogatott politikák, amelyek közvetlen előnyökkel járnak a szomszédos országok számára is.

\section{A 2014-2020-as költségvetési keret kiadási szerkezete}

A kiadási fejezetek átalakításában a 2007 és 2013 közötti többéves keret hozott áttörést. Jelzésértékű volt a megfogalmazott prioritások sorrendje, a kiadási fejezetek új elnevezése és néhány esetben az új tartalmi elemek megjelenése is (EP-Council of $E U-E C$ [2006]). A költségvetési fejezetek sorrendjében a fenntartható növekedést befolyásoló szakpolitikák és a kohéziós politika került az első helyre. Az új költségvetési fejezetcímek ellenére a 2007 és 2013 közötti többéves pénzügyi keret az egyes területekre fordított kiadások összegét nézve nem hozott radikálisan eltérö kiadási arányokat (Kengyel [2016]).

A 2014 és 2020 közötti időszakra szóló többéves pénzügyi keret új kiadási fejezetcímei valójában csak megfogalmazásukban térnek el a megelőző időszak kiadási tételeinek elnevezéseitől, tartalmilag teljesen azonos szakpolitikai területeket támogatnak ( $E C$ [2011]). A keretterv pozitív üzenetet közvetített azzal, hogy az Európa 2020 stratégiára füzte fel az egyes kiadási tételeket ( $E B$ [2010]). A kiadások legnagyobb részét (körülbelül 70 százalékát) azonban 2014 és 2020 között is a két hagyományosan meghatározó szakpolitikára: az agrár- és a kohéziós politikára fordítjuk. Emiatt a többi szakpolitika esetében eléggé korlátozott mértékben tolódhattak el az arányok. A kiadások arányaiban mégis megfigyelhető egy fokozatos elmozdulás: az 1.a alfejezet (versenyképesség) kiadásai emelkednek, az 1.b alfejezet (a kohéziós politika) és az agrárpolitika kiadásai viszont csökkenést mutatnak. A fejezetek elnevezése a következőképpen alakult:

1. Intelligens és inkluzív növekedés (a kiadások a teljes keret 47 százalékát teszik ki: az 1.a alfejezetre 13, az 1.b alfejezetre 34 százalék jut);

2. Fenntartható növekedés: természeti erőforrások (a fejezet részaránya 39 százalék; az agrárpolitika 1. pillére 29, a vidékfejlesztési pillér 9 százalékot ér el - a többi kiadást a halászat és a környezetvédelem támogatására fordítják, amelyek támogatására a fejezet kiadásainak töredéke jut);

3. Biztonság és állampolgárság (a kiadások részaránya a keret alig 2 százalékát éri el);

4. Globális Európa (a keret 6 százalékát teszi ki);

5. Igazgatás (nagyjából szintén 6 százalékos részesedést ér el). 
Az egyes kiadási fejezetek közötti megoszlást mutatja az 5. ábra.

5. ábra

A 2014-2020 közötti többéves pénzügyi keret kiadási oldala (százalék)

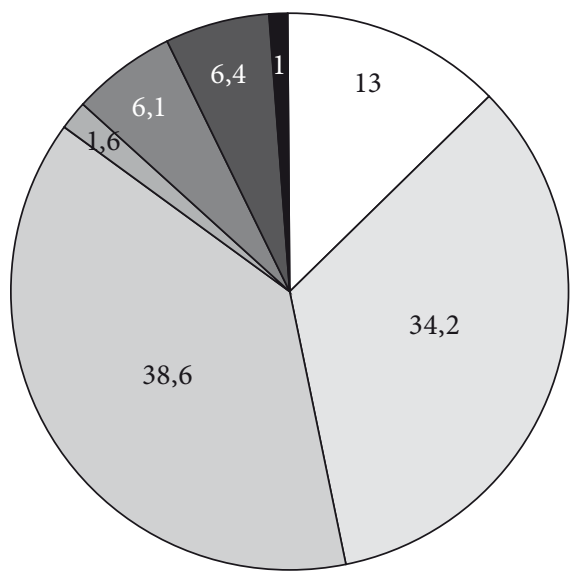

1.a Versenyképesség a növekedésért és foglalkoztatásért

1.b Gazdasági, társadalmi és területi kohézió

2. Fenntartható növekedés:

természeti erőforrások

3. Biztonság és állampolgárság

4. Globális Európa

5. Igazgatás

Kompenzáció

Forrás: EU Tanácsa [2013].

A 2014 és 2020 közötti költségvetési keretről folytatott vitában az álláspontok a megelőző időszakok keretköltségvetéseiről folytatott vitákból jól ismert törésvonalak mentén alakultak. A nettó befizető, gazdagabb tagállamok eleve elhatárolódtak a kiadások növelésétől, sőt reálértékben csökkenést kívántak elérni. Pedig elvileg helytálló volt az a Barroso - akkori - bizottsági elnök által sokszor emlegetett igazság, hogy „nem lehet több Európát kevesebb pénzből építeni”. Ebben az időszakban a tagállamok államháztartási nehézségei és a világgazdasági válság szolgáltatta a legfőbb érvet a kiadások csökkentése vagy legfeljebb szinten tartása mellett. ${ }^{9}$

A végső megállapodás szerint a kifizetések föösszege 960 milliárd euróra, a GNI 0,95 százalékára csökkent. A kötelezettségvállalási előirányzat a GNI 1 százalékát éri el, szemben a 2007 és 2013 közötti 1,12 százalékos szinttel. A kohéziós és az agrárpolitikára szánt összegek csökkentek a 2007-2013-as időszakhoz képest. A többi tétel esetében a kiadások mértéke némileg emelkedett; leginkább az 1.a alfejezethez kapcsolódó területekre fordított összegek növekedése számottevő (átlagosan 37 százalékos), különösen a kutatás-fejlesztés, az oktatáspolitika és a transzeurópai hálózatokat támogató új alap költségvetése esetében. ${ }^{10}$ A 2014

${ }^{9}$ Ez az érvelés az 1 százalék körüli GNI-arányos jövedelem-újraelosztásnál igazából nem vehető komolyan. Ismertek a szövetségi államok költségvetéseivel való összevetések, amelyek rámutatnak arra, hogy az uniós szintű kiadások GDP-arányosan a harmincad részét sem érik el a föderális költségvetéseknek, a nemzeti költségvetéseknek pedig gyakorlatilag ötvened részéről van szó.

${ }^{10}$ Kedvező változás a versenyképesség javításához kapcsolódó három terület költségvetésének komoly növelése. Az oktatáspolitikát támogató Erasmus+ programra folyó árakon közel 15 milliárd euró (2011. évi árakon 13 milliárd euró) jutott, ami reálértéken mintegy 40 százalékkal több a korábbi hétéves időszak keretéhez képest. Az uniós szintű kutatási és innovációs támogatásokra a Horizont 2020 keretprogramban folyó árakon közel 80 milliárd euró (2011. évi árakon 70 milliárd euró) állt rendelkezésre, ami reálértéken számítva mintegy 30 százalékkal több az előző költségvetési ciklus idején 


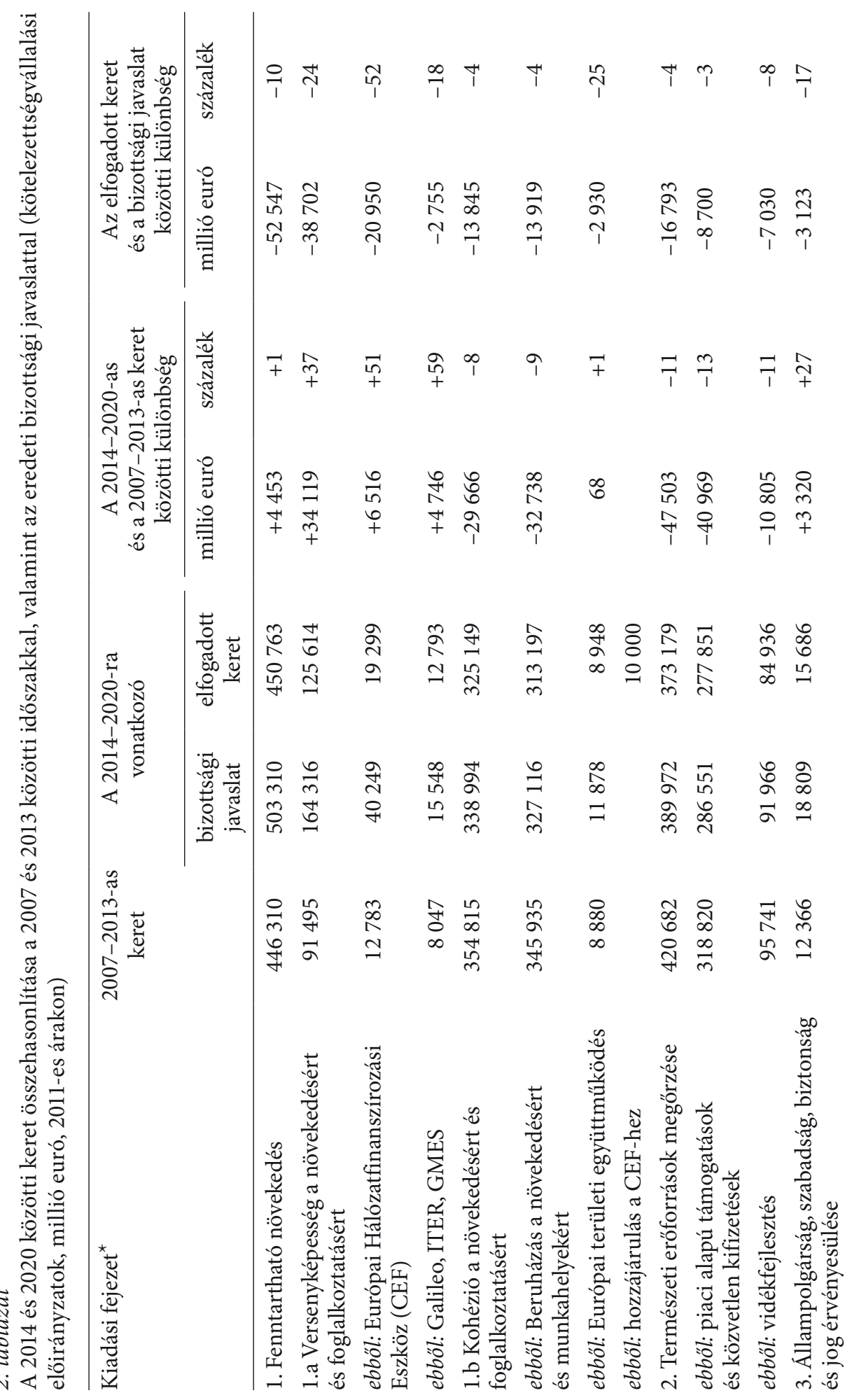




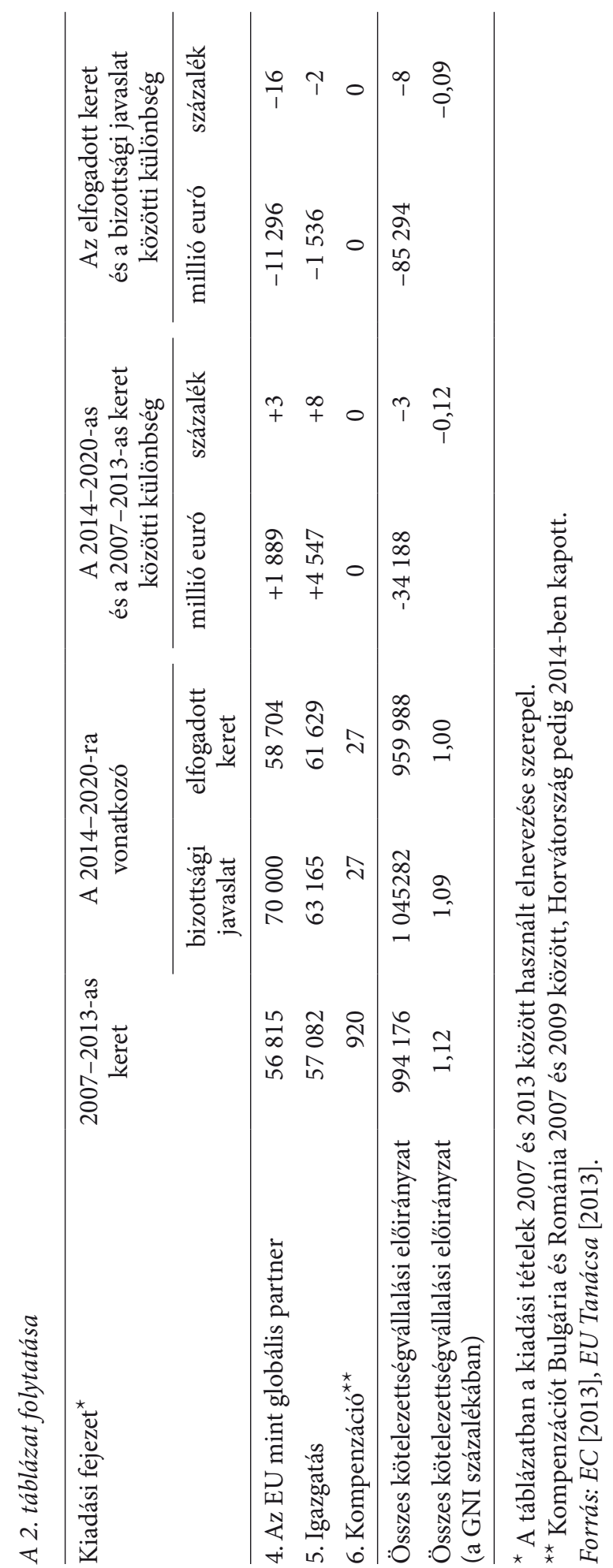


és 2020 közötti keretköltségvetésre tett eredeti bizottsági javaslatot összevetve a végső megállapodás számaival, valamint a megelőző hétéves időszak kiadásaival, megállapítható, hogy a viták során kevésbé radikális elmozdulásról született megegyezés. Emellett azt is meg kell jegyezni, hogy az Európai Unió történetében elöször következett be az, hogy az elfogadott költségvetési keret kifizetései reálértéken - 3 százalékkal - csökkentek (2. táblázat).

\section{A 2021 és 2027 közötti többéves pénzügyi keretben javasolt változtatási irány}

A Bizottság 2018. május 2-án hozta nyilvánosságra a 2021 és 2027 közötti időszakra vonatkozó javaslatcsomagját (EB [2018c]). Az ebben meghatározott prioritások megalapozottságának alátámasztásaként a Bizottság többek között hivatkozott a 2017. március 1-jén megjelent Fehér könyv Európa jövőjéről című összeállítására, 27 tagállam vezetőjének a római szerződés aláírásának 60. évfordulója alkalmából 2017. március 25-én Rómában elfogadott nyilatkozatára és az Európai Unió pénzügyeinek jövőjéröl 2017 júniusában kiadott bizottsági vitaanyagra, amelyek hatással voltak a változtatások irányára. Az említett fehér könyvben a Bizottság öt forgatókönyvet állított fel, a vitaanyag pedig a közös költségvetés jellemzőinek részletes számbavétele alapján vázolta fel az egyes - egymástól az integrációs együttműködés jövőbeli szorosságának mértékében különböző - forgatókönyvekhez kapcsolódó lehetséges költségvetési következményeket (EB [2017a], [2017b]).

A 2021 és 2027 közötti időszakra való felkészülés terén a két bizottsági háttérdokumentum mellett a 27 tagállam vezetője által aláírt római nyilatkozat azért stratégiai jelentőségü, mert kifejeződött benne, hogy a tagállamok a közös érdekek és értékek alapján együtt kívánnak fellépni, és a célok eléréséhez az Európai Uniót tartják a megfelelő keretnek (EC [2017]). A nyilatkozat értelmében a közösen meghatározott célkitűzéseket négy fó témakör köré csoportosították: 1. biztonságos Európa; 2. fenntartható Európa, amelyet összehangolt belső piac és strukturális reformok jellemeznek; 3. szociális Európa, amelyben tagállami szociális rendszerek működnek, de közösen harcolnak a munkanélküliség ellen és az egyenlő szociális jogokért; 4. nemzetközi szinten erősebb Európa, amely szövetségeket köt a világban.

A fehér könyvben bemutatott öt forgatókönyv csak szemléltető jellegü, gondolatébresztő elörejelzéseket tartalmaz, vagyis nem részletesen kidolgozott ütemtervekről, kész szakpolitikai szabályozásokról szól. A dokumentum az Európai Unió helyzetét jellemző lényeges területeket sorra véve többek között rámutat arra, hogy Európa a világ legnagyobb egységes piacával rendelkezik, az első számú kereskedelmi nagyhatalom, az innováció egyik éllovasa, és nemzetközi szerepvállalásának köszönhetően kiemelkedő szerepet tölt be a nemzetközi fejlesztési segélyezés és a 2030-ra

biztosított összegnél. A transzeurópai hálózatok (TEN) fejlesztését támogató új Európai Hálózatfinanszírozási Eszköz (Connecting Europe Facility, CEF) folyó árakon 33,3 milliárd euró (2011. évi árakon 29 milliárd euró) keretet kapott, ami a TEN-hez kapcsolódó korábbi támogatásokat mintegy 50 százalékkal haladta meg (EB [2013]). 
kitűzött fenntartható fejlesztési célok megvalósítása terén. A dokumentum arra is utal, hogy a nemzetközi terrorizmus erősödése okozta belső és külső fenyegetések miatt az uniós polgárok biztonsága kiemelkedően fontos üggyé vált. Emellett megállapítja azt is, hogy a migrációt kiváltó nyomás erösödik, a menekültügyi válság pedig a második világháború óta nem tapasztalt méreteket öltött. Tehát a dokumentum számos témakörre hívja fel a figyelmet, amelyekhez értelemszerủen megfelelő költségvetési forrásokat is biztosítani kell (EB [2017a]).

A felvázolt öt forgatókönyv és azok költségvetési következményei az alábbiakban foglalhatók össze.

1. A „minden megy tovább” forgatókönyv a kialakult és megreformált programok támogatásának folytatását jelenti.

2. A „csakis az egységes piac” forgatókönyv a hangsúlyokat az egységes piachoz szükséges alapvető funkciók finanszírozására helyezné. Másképpen megfogalmazva ez a „kevesebbet együtt” forgatókönyve.

3. Az „aki többet akar, többet tesz” forgatókönyv a megreformált programok finanszírozása mellett lehetővé tenné, hogy néhány tagállam részére kiegészítő költségvetést biztosítsanak azokon a területeken, amelyeken többet kívánnak tenni.

4. A „kevesebbet hatékonyabban” forgatókönyv jelentősen átalakítaná a költségvetést, új prioritásokat fogalmazva meg. Ez azzal is járna, hogy az Európai Unió bizonyos területeken többet tesz, más területeken viszont kevesebbet.

5. A „sokkal többet együtt” forgatókönyv szerint új saját forrásokból történő finanszírozással jelentősen korszerüsítenék és megnövelnék a költségvetést, és belépne az euróövezet költségvetési stabilizációs funkciója is.

A fehér könyv és a vitaanyag számos hasznos felvetésének elismerése mellett meg kell jegyeznünk, hogy a forgatókönyvek közötti választás karakteresen nem jelent meg a tagállamok közötti nyilvános vitákban, így nem igazán érzékelhető, hogy az öt változat közül valamelyiket átültették volna a gyakorlatba. Mint ahogyan a 2021 és 2027 közötti többéves pénzügyi kerettervre vonatkozó bizottsági javaslatcsomag kapcsán sem derül ki, hogy milyen alapon és melyik forgatókönyvet vette figyelembe a Bizottság a tervezet elkészítésekor.

A Bizottság a 2018 májusában megjelent javaslatcsomagban modern, egyszerü és rugalmas költségvetésként jellemzi a 2021 és 2027 közötti időszakra vonatkozó tervezetet, amit a következőkkel támaszt alá (EB [2018a]).

- Modern: csökkenti a bürokráciát a kedvezményezettek és az irányító hatóságok számára, mert egységes szabálykönyvet fogalmaz meg, és koherensebbé teszi a szabályokat. Emellett egyértelmü célokat határoz meg, és nagyobb hangsúlyt helyez a teljesítményre.

- Egyszerű: a költségvetés jobban tükrözi az Európai Unió prioritásait, szerkezete egyértelmübbé válik, a programok száma több mint egyharmaddal csökken (a jelenlegi 58-ról 37-re).

- Rugalmas: nagyobb rugalmasságot biztosít a programok közötti és azokon belüli átcsoportosításokhoz, a válságkezelési eszközök megerösítésével és egy új „uniós tartalék” létrehozásával jobban felkészül az előre nem látható események kezelésére. 
A tagállamok közötti tárgyalásokat a Bizottság eredeti elképzelései szerint már a 2019. májusi európai parlamenti választások előtt, illetve az új Bizottság felállítását megelőzően le kellett volna zárni. Ez a korábbi többéves pénzügyi keretekről folytatott viták tapasztalatai alapján egyáltalán nem tủnt reális várakozásnak, hiszen a folyamat jellemzően átlagosan legalább két évig szokott tartani. A megállapodás gyors elérése kiváltképp nem tűnt megvalósíthatónak amiatt, hogy a Bizottság által javasolt változtatások több szakpolitika esetében is éles vitákat tettek valószínűvé. A 2020 utáni költségvetés tervezése során a brexit miatt bekövetkező forráscsökkenés problémájának megoldása (az évi körülbelül 10 milliárd eurós kiesés pótlása) mellett ugyanis a kiadási szerkezet változtatása is szükségessé vált, mert olyan új prioritások merültek fel (mint például a migráció és a menekültügy kezelése), amelyekre korábban nem állt rendelkezésre számottevő finanszírozás. Ráadásul ezen új területek támogatása kapcsán is számos eltérő szempont fogalmazódik meg. Az új programok támogatása értelemszerúen jelentősebb átcsoportosításokat tesz szükségessé, vagyis a hagyományos szakpolitikákra fordított keretek jelentős csökkentésének kérdése is napirendre került. ${ }^{11}$

A tervezet alapján a 2021 és 2027 közötti többéves pénzügyi keretterv kötelezettségvállalási előirányzatokban kifejezve összesen 1135 milliárd eurót tenne ki 2018as árakon számolva (ez folyó árakon 1279 milliárd eurónak felel meg), ami az EU27 bruttó nemzeti jövedelmének 1,11 százaléka. A tényleges kifizetések 1105 milliárd euró kiadást jelentenének 2018-as árakon, ami az EU27 GNI-jének 1,08 százaléka. A javasolt keret nagyságában bekövetkezö változást árnyaltan kell értékelni, mivel két fontos tény is nehezíti a 2014 és 2020 közötti kiadásokkal történő összehasonlítást: az egyik a brit kilépés, a másik pedig az Európai Fejlesztési Alap (EFA) kiadásainak beemelése a közös költségvetésbe. ${ }^{12} \mathrm{~A}$ britek kilépése miatt ráadásul nemcsak az EU összesített bruttó nemzeti jövedelmének csökkenését kell számításba venni az összevetés során, hanem a 2014-2020-as keretből a britekre fordított kiadásokat is le kell vonni. Ha az EU28-ra vonatkozó 2014 és 2020 közötti kerettel vetjük egybe a bizottsági javaslatot, akkor reálértéken kismértékü csökkenés következik be. Ha viszont a britek nélkül átszámított 2014 és 2020 közötti kerettel vetjük egybe a javaslatot, akkor reálértéken 5 százalék körüli növekedés következik be. Ha pedig a jelenlegi keret EU28-ak GNI-jéhez viszonyított 1,03 százalékos szintjével hasonlítjuk össze a kötelezettségvállalások szintjén javasolt 1,11 százalékos arányt, akkor látszólag növekszik a keret, ugyanakkor az Egyesült Királyság nélkül számítva a 2014 és 2020 közötti keret az EU27-ek GNI-jének 1,16 százalékát tette ki (az EFA forrásait is beleszámítva) - tehát a 2021-2027-es keret GNI-arányosan csökkenő irányzatot mutat.

A Bizottság javaslata szerint a korábbi öt helyett hét fejezetbe, azokon belül pedig 17 „szakpolitikai területre” csoportosítanák a kiadásokat. A szakpolitikákat támogató

\footnotetext{
${ }^{11}$ Ez a forgatókönyv persze a közös költségvetés fő kedvezményezettjeinek komoly ellenállásába ütközik.

${ }^{12}$ A 2014 és 2020 között 30 milliárd euróból gazdálkodó Európai Fejlesztési Alap - amely eddig a közös költségvetésen kívül müködött - a tervezet szerint bekerül az uniós költségvetésbe. Az alap kiadásai a GNI 0,03 százalékát képviselik.
} 
programok számát a javaslat értelmében csökkentik úgy, hogy az eddig széttagolt finanszírozási forrásokat integrált programok váltják fel. A javaslat számos esetben a korábbi fejezetek közötti átcsoportosításokat is tartalmaz, ezért a 2014-2020-as kerettel való összehasonlítás során az egyes kiadásokat nem egyszerű megfeleltetni a korábbi fejezetek kiadásainak.

A javaslatcsomag szerint a 2021-2027-es többéves pénzügyi keret új kiadási szerkezete a következőképpen alakulna (2018-as árakon):

1. kiadási fejezet: az egységes piac, innováció és digitális gazdaság (166 milliárd euró). A fejezet lényegében a korábbi 1.a alfejezet fö kiadási tételeit tartalmazza, de az oktatás az új 2. fejezetbe kerül át. Jelentősen erősödne a digitális gazdasághoz és az innovációhoz kapcsolódó programok támogatása, a versenyképesség javítása. ${ }^{13}$

2. kiadási fejezet: kohézió és értékek (392 milliárd euró). Az új kiadási fejezetnek a gazdasági, társadalmi és területi kohézió (331 milliárd euró) támogatása mellett része lenne a monetáris unió müködéséhez kapcsolódó tétel, ${ }^{14}$ valamint az oktatás, a kultúra, továbbá a jogok és értékek támogatása is.

3. kiadási fejezet: természeti erőforrások és környezet (337 milliárd euró). A fejezet megfeleltethető a korábbi 2. fejezet tartalmának, a fó kiadási tétel továbbra is az agrárpolitika első pillére (a piachoz kapcsolódó kiadásokra és közvetlen kifizetésekre 254 milliárd euróval).

4. kiadási fejezet: migráció és határigazgatás (31 milliárd euró). A korábbi 3. fejezet fö tételei, de jelentős feladat- és forrásbővüléssel.

5. kiadási fejezet: biztonság és védelem (24 milliárd euró). Részben a korábbi 3. fejezet egyes részprogramjainak folytatása, de nagyrészt teljesen új területek támogatása is megjelenik, mint például a védelem.

6. kiadási fejezet: szomszédság és a világ (109 milliárd euró). A korábbi 4. fejezetben szereplő külső támogatási programok folytatása, beemelve az Európai Fejlesztési Alap kiadásait is.

7. kiadási fejezet: európai közigazgatás (76 milliárd euró); ebből az Európai Unió intézményeinek igazgatási kiadásaira 59 milliárd euró jutna.

A tervezett kiadási fejezetek részarányát mutatja be a 6. ábra.

\footnotetext{
${ }^{13}$ Például az új, integrált „InvestEU Alap” egyetlen programban fogja össze az EU-szerte stratégiai beruházásokat támogató, központilag irányított finanszírozási eszközöket.

${ }^{14}$ A gazdasági és monetáris unió működésének stabilitása érdekében a Bizottság két új eszközre tett javaslatot. Az egyik a 2. kiadási fejezet keretében működő reformtámogató program, a másik a közös költségvetésen kívül létrehozandó európai beruházásstabilizáló funkció lenne. Az új eszközök hozzájárulnának az euróövezet makrogazdasági stabilitásának fenntartásához: támogatnák a megfelelő strukturális reformokat és a beruházási aktivitás fenntartását. A reformtámogató program 25 milliárd eurós költségvetéssel rendelkezne, magában foglalva egy reformtámogató és egy konvergenciatámogató eszközt; az előbbi valamennyi, az utóbbi az euróövezeti csatlakozás előtt álló tagállamok számára nyújtana támogatást. Az európai beruházásstabilizáló funkció a jelentősebb aszimmetrikus sokkhatások esetén segítené fenntartani a beruházási aktivitást. Egy legfeljebb 30 milliárd euróval garantált hitelkeret formáját öltené, amelyhez a visszafizetés napján a tagállamnak a kamatfizetések fedezésére nyújtott pénzügyi támogatás társul (EC [2018a]).
} 
A 2021 és 2027 közötti többéves pénzügyi keret tervezett kiadási oldala

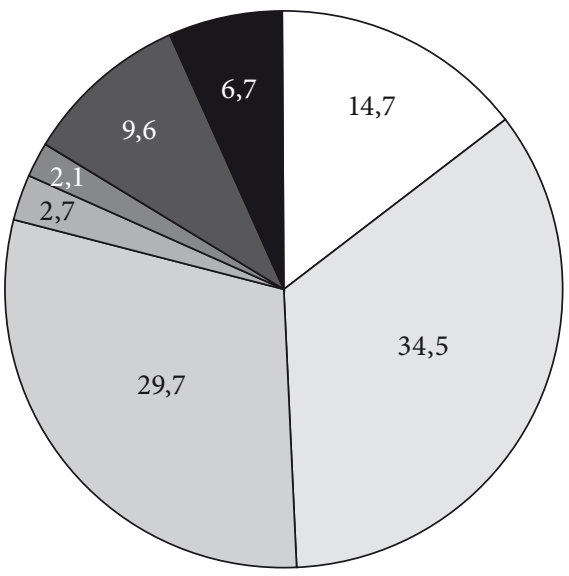

$\square$ 1. Egységes piac, innováció és digitális Európa

2. Kohézió és értékek

3. Természeti erőforrások és környezet

4. Migráció és határigazgatás

5. Biztonság és védelem

6. Szomszédság és a világ

7. Európai közigazgatás

Forrás: EB [2018c].

Mivel a tárgyalások kiindulópontja az, hogy a meghatározó tagállamok nem hajlandók nagyobb közös költségvetésben gondolkodni (hiszen a brexit miatt így is emelni kell a befizetéseket), elvileg csak a hagyományosan legnagyobb mértékben támogatott két szakpolitikára fordított keretek csökkentésével szabadíthatók fel olyan összegek, amelyeket más szakpolitika megerősítésére, illetve új prioritások támogatására lehet költeni. (A szóban forgó két szakpolitika lényeges szerepét a jövőben sem kérdőjeleznék meg: a bizottsági javaslat szerint mindkettő 29-29 százalékkal részesedne a következő hosszú távú keretköltségvetés forrásaiból.)

Az e két szakpolitika költségvetési forrásainak lefaragására vonatkozó javaslatot ugyanakkor - megdöbbentő módon - a Bizottság által kiadott valamennyi dokumentum (EB [2018a], [2018b]) csak mintegy 5-5 százalékos csökkenésként mutatta be. Ugyanis az összehasonlításban nem reálértéken és nem is a britek nélkül számított jelenlegi költségvetési kiadásokkal összevetve mutatták be a változást, hanem egyszerűen folyó áron számoltak. A számokat nézve nagyon hamar kiderült a nem igazán transzparens hozzáállás, amit az Európai Parlament és több kutató is felrótt (EP [2018], Donati [2018], Matthews [2018], Parry-Sapala [2018]). Ugyanis valójában - reálértéken - a közös agrárpolitikára fordítandó kiadások 15, a kohéziós politikai támogatások pedig 11 százalékkal csökkennének. Ezeken belül például a Kohéziós Alap költségvetése 45, az Európai Mezőgazdasági Vidékfejlesztési Alapé pedig 28 százalékkal lenne kisebb. Ugyanakkor a változások folyó áron történő bemutatásával a Bizottság a nagyobb támogatásban részesülő területek esetében a bekövetkezőnél jóval nagyobb keretnövekedést mutatott ki. Az egyes területeken ténylegesen bekövetkezö, összehasonlító áron számolt változásokat a 3. táblázat mutatja be.

A 3. táblázatból jól látható, hogy a briteknek járó kifizetések nélkül kalkulált 20142020-as kiadásokhoz viszonyítva konstans áron számítva milyen mértéküek az egyes szakpolitikák esetében javasolt változások. Emellett azt is mutatja a táblázat, hogy 


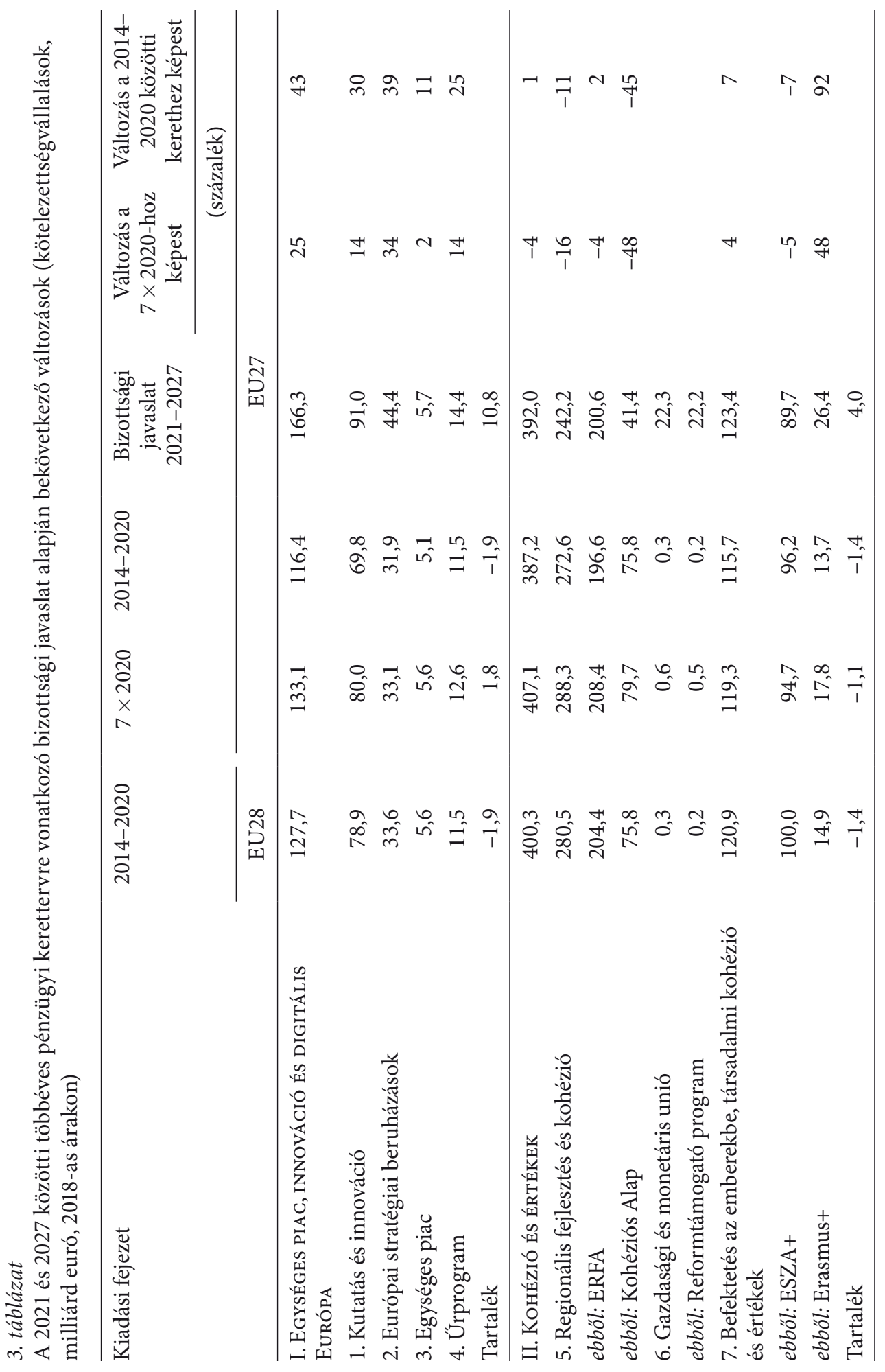




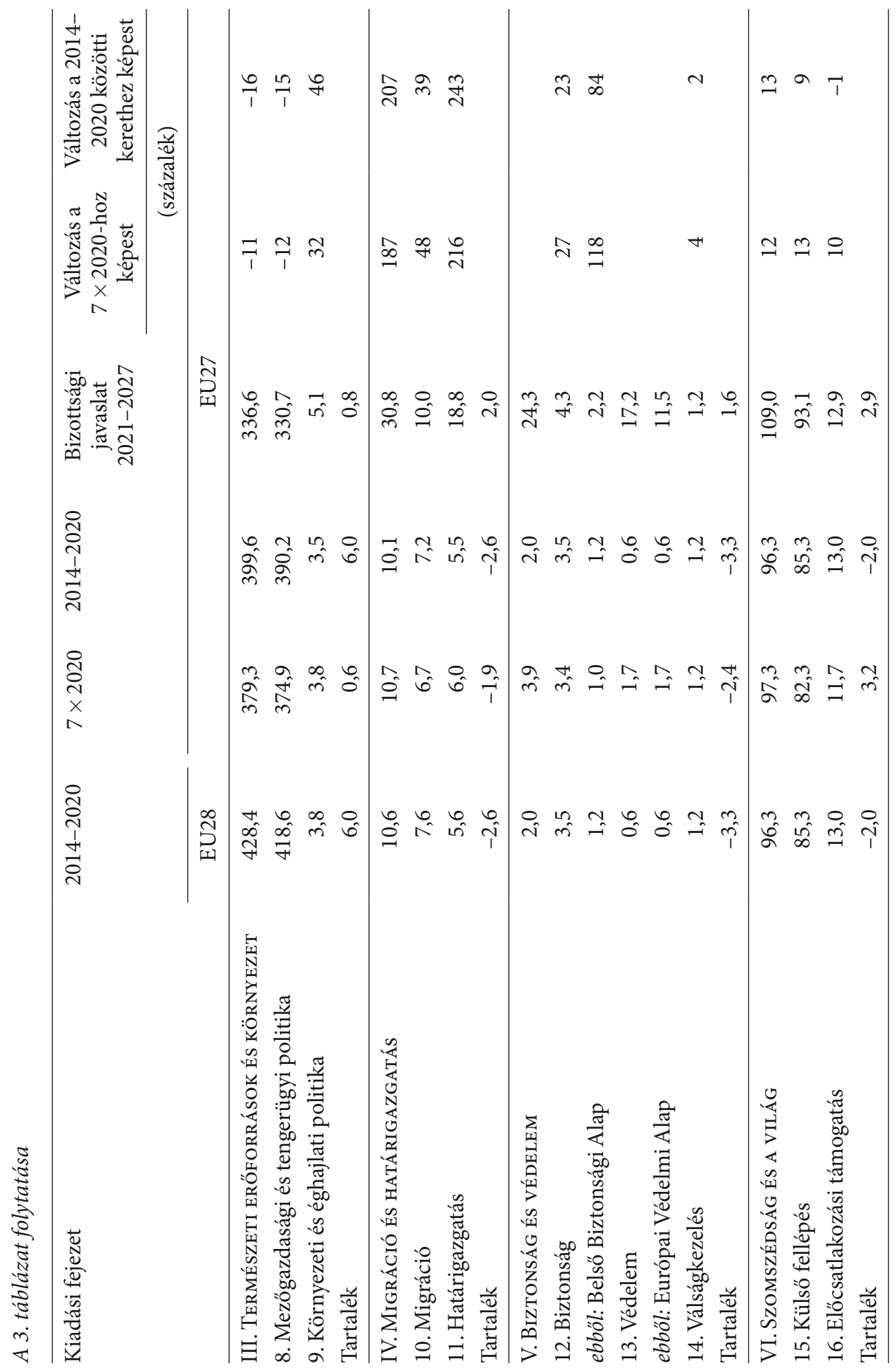




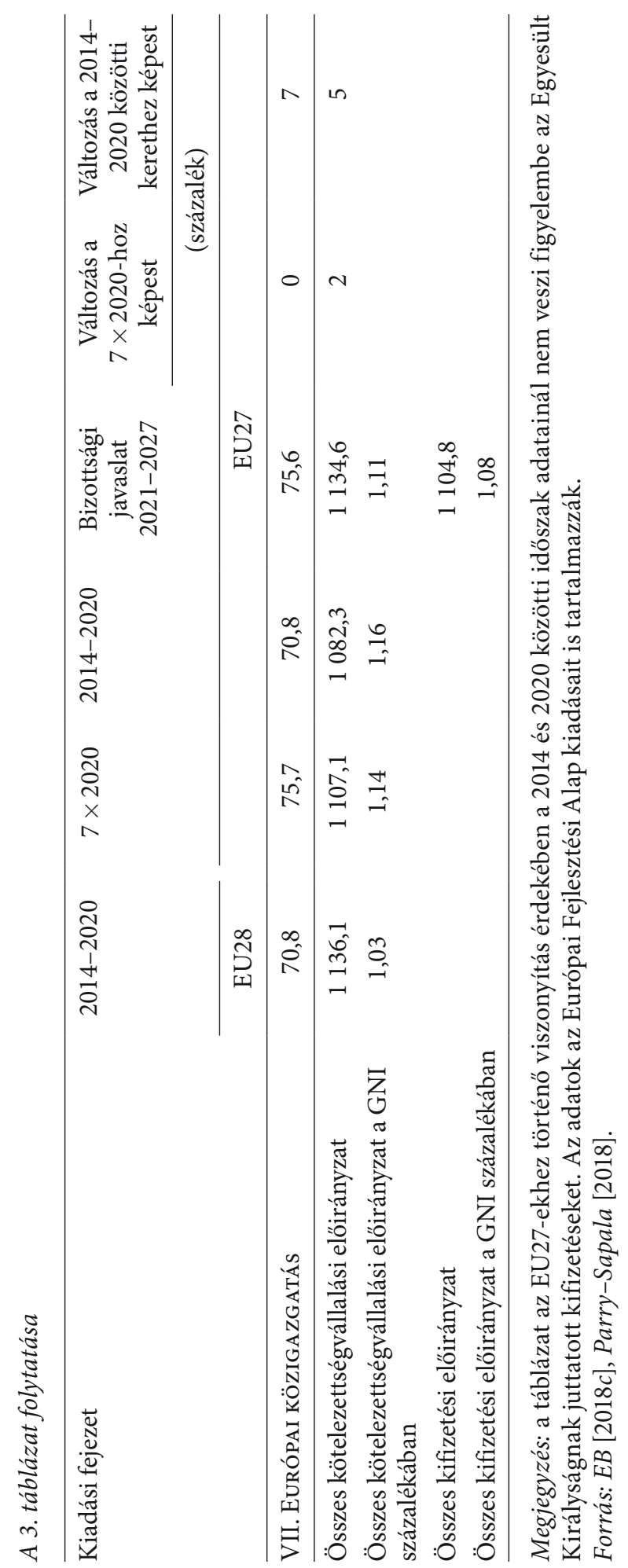


a változások mértékének reális megítélésében az sem elhanyagolható szempont, hogy a 2014 és 2020 közötti időszak hétéves keretösszegéhez viszonyítjuk-e a változást, avagy az időszak utolsó évében, 2020-ban elért kiadások hétszeresét tekintjük összehasonlítási alapnak. A javaslatcsomag értelmében kétségtelen, hogy több kulcsfontosságú területen következne be a kiadások jelentős emelkedése, de korántsem akkora mértékben, mint ahogyan azt a Bizottság a hivatalos anyagaiban bemutatta.

- Például a kutatás és innováció területén nem 50, hanem 30 százalékkal emelkedne a kiadások összege, ha pedig a 2020-ra elért szint hétszeresét vesszük alapul, a növekedés már csak 14 százalékos lenne.

- Az oktatást támogató Erasmus+ program költségvetésére sem jutna több mint kétszer akkora forrás (bár a 92 százalékos emelkedés is nagyon jelentős); a 2020-ra elért évi kiadási szinthez képest viszont már „csak” 48 százalékos a növekedés.

- A bizottsági bejelentéssel szemben a külső határok igazgatására, a migráció kezelésére és a menekültügyre fordított kiadások nagysága sem közel háromszorosára, hanem nagyjából kétszeresére emelkedne (207, illetve 187 százalékkal lenne magasabb a tervezett kiadások összege).

A Bizottság által javasolt változások mértékéről még éles viták folynak majd a tagállamok között és az Európai Tanácsban, $\mathrm{s}$ - a korábbi időszakok tárgyalásaihoz hasonlóan - most is biztosra vehető, hogy a végső kompromisszum eredményeként a tervezett kiadáscsökkentések, illetve -növelések szerényebb mértéküek lesznek.

\section{Következtetések}

Az eddigi tapasztalatok alapján úgy tünik, hogy a 2021 és 2027 közötti hosszú távú költségvetésről folyó viták eredményeként áttörés ugyan nem fog bekövetkezni sem a bevételi, sem a kiadási oldalon, de elindulhat egy bizonyos fokú átstrukturálódás. Az új saját források bevezetésére vonatkozó javaslat mellett nem érzékelhető átütő erejü támogatás, mivel azok csak bonyolítanák és kevésbé kiszámíthatóvá tennék a költségvetés finanszírozását, és nem szüntetnék meg a GNI-alapú hozzájárulás meghatározó szerepét. A kiadási oldalon ugyanakkor egyes programok esetében jelentős elöretörés következhet be, még akkor is, ha az ezekre a területekre fordított kiadások részaránya az egész kereten belül viszonylag kicsi marad.

A közös költségvetésről folytatott tárgyalások során a tagállamok által képviselt nettó pozíciós szemlélet nagyon megnehezíti bármiféle jelentősebb változtatás végrehajtását. Az uniós szintű kiadásokból származó európai hozzáadott értéket (ami minden tagállam számára előnyökkel jár) kellene a vita középpontjába állítani. A tagállamokat jellemző hozzáállás alapján kijelenthető, hogy az unió előtt álló célok támogatását a 2021-2027-es költségvetési időszakban is meglehetősen szűk kereteken belül lehet majd finanszírozni. Az új vagy megerősítendő prioritások támogatása csakis a hagyományosan meghatározó súllyal rendelkező két nagy szakpolitika: a kohéziós és az agrárpolitika költségvetési keretének számottevő csökkentésével lehetséges. Ez a forgatókönyv viszont a jelenlegi fö haszonélvezö országok ellenállásába ütközik, 
ezért a tagállamok közötti tárgyalások eredményes lezárásához végül valószínűleg csak mérsékeltebb változtatásokra nyílik lehetőség.

A 2021-2027-es időszakra javasolt többéves pénzügyi keretről ugyanakkor kijelenthető, hogy elötérbe helyez számos olyan meghatározó területet, amelyek valóban stratégiai jelentőségủek az egész integrációs folyamat szempontjából. Ugyanis gazdasági téren az Európai Unió legfőbb feladata a versenyképesség és a konvergencia erősítése. Ennek motorját a belső piac megfelelő müködése mellett a kohéziós politikai támogatások jelentik. Ezt a javasolt költségvetés kiadási tételei figyelembe veszik: a költségvetés az integráltabb és versenyképesebb Európa megteremtéséhez a maga eszközeivel hozzá tud járulni a kutatás-fejlesztés, az innováció, a digitális gazdaság, az oktatás és az infrastruktúra területeire jutó kiadások növelésével. A közös költségvetésnek a válságkezelésben és a sokkok abszorbeálásában is fontos szerepet kellene betöltenie. Itt a stabilizációs funkció erősítésének igénye merülne fel, amelynek keretei az új 2. kiadási fejezeten belül megjelennek, de viszonylag szűkre szabottak lennének. Emellett az integrációt érő új kihívások is (mint amilyen a migrációs és menekültválság belső és külső következményei) megfelelő uniós szintű válaszok és finanszírozási keretek kialakítását igénylik. Az erre vonatkozó javaslatok is megszülettek: jelzésértékü ezen új prioritások két önálló kiadási fejezet formájában történő megjelenése. A megfelelő nemzetközi szerepvállalás keretei is integráltabbá válnának.

A hosszú távon megnyíló elmozdulási lehetőségek megítéléséhez a jelenlegi és a korábbi költségvetési keretekről folytatott tárgyalások tapasztalatai alapján érdemes rámutatni néhány olyan általános jellemzőre, amely döntően befolyásolja a jövőbeli változtatások irányait és korlátait is.

- Az intézményrendszer működése és a tagállamok érdekeinek figyelembevétele egy technokrata, bürokratikus, szabályalapú döntéshozatalt hozott létre, amely csak lassan képes reagálni a változásokra. Emiatt jelentős mértékủ útfüggőség jellemzi a költségvetésben véghezvihető reformokat, vagyis a jövőbeli változtatásokat nagymértékben meghatározza a kialakult struktúra. Az egyes kiadási tételek közötti arány csak lassan, fokozatosan tud eltolódni.

- A tagállamoknak vannak közös céljaik, a kérdés az, hogyan finanszírozzák elérésüket. Az uniós szintű fellépés indokoltságát elvileg az európai szintü kiadások hozzáadott értékével lehet alátámasztani. Vagyis az adott kiadásból minden tagállam számára kölcsönös elönyök származnak, és az uniós kiadások hatékonyabbak, mint ha a nemzeti költségvetésekből támogatnának adott szakpolitikai célokat, illetve csak így valósulhat meg valamilyen cél. A tagállamoknak azt kellene szem előtt tartaniuk, hogy a közös költségvetés tényleges hatásait a szüken értelmezett nettó költségvetési pozíció önmagában egyáltalán nem képes tükrözni.

- Az uniós költségvetésnek más funkciói vannak, mint egy nemzeti költségvetésnek, ebböl adódóan számos területet nem finanszíroz. Meghatározó részében lényegében egy beruházási költségvetés. Ennek az a következménye, hogy bizonyos kiadások az uniós költségvetésben aránytalannak tünnek (például a közös agrárpolitika finanszírozása), de ezt az Európai Unió szintjén vállalt funkciók és a közkiadásokon belüli arányok alapján már másképpen lehet megítélni. Tehát az egyes kiadási tételek 
részesedését nem szabad önmagukban értékelni: a kiadásokat az összes közkiadáson belül betöltött részarányuk, illetve az EU hatáskörei tükrében kell minősíteni. Az uniós költségvetésnek alapvetően kiegészítő szerepe van. Tény azonban, hogy azokon a területeken, ahol számottevő forrásokkal rendelkezik, korlátozott nagysága ellenére a szerepe viszonylag jelentős.

- A többéves keret lényeges jellemzője a stabilitás, ugyanakkor bizonyos mértékű rugalmasságra is szükség van. A stabilitás különösen fontos a többéves programok kiszámítható költségvetési háttere miatt. A rugalmasság viszont lényeges az előre nem látható helyzetekre adandó gyors reagálás lehetőségének biztosításához. Ez utóbbi kapcsán a félidős felülvizsgálatnak, a fejezeteken belüli átcsoportosításnak, illetve a megfelelő tartalékok beállításának lehet fontos szerepe.

Az uniós költségvetés jövőjéről való gondolkodás során olyan megközelítések is napvilágot láttak már, miszerint annak tervezését nem a kialakult keretek alapján kellene elvégezni, hanem a nulla bázisú tervezési módszer alkalmazásával teljesen újra kellene tervezni (Tarschys [2007]). Így csak a megfelelően alátámasztott célok kerülnének bele a költségvetésbe, és akár egészen más eredmény születhetne az egyes fejezetekre és a teljes keretösszegre vonatkozóan is. Ez nehezen megvalósítható, bár elvileg valóban logikusnak tünhet. Az mindenképpen leszögezhetö, hogy az elmúlt évtizedek tanulságai alapján az uniós szintű költségvetés jövője nagyon kényes politikai ügy, ezért fontos, hogy a jövőben is megfelelő egyensúlyt lehessen biztosítani az egyes tagállamok érdekei és az egyes szakpolitikai területek előtt álló közös célok megvalósításának támogatása között.

\section{Hivatkozások}

BegG, I. [2009]: Fiscal Federalism, Subsidiarity and the EU Budget Review. SIEPS Report, No. 1.SIEPS, Stockholm, http://eprints.lse.ac.uk/23811/2/Fiscal_federalism_subsidiarity_ and_the_EU_budget_review.pdf.

Cipriani, G. [2014]: Financing the EU Budget. Moving Forward or Backwards? Centre for European Policy Studies, Brüsszel, Rowman and Littlefield International, Ltd. https://www. ceps.eu/system/files/Financing\%20the\%20EU\%20budget_Final_Colour.pdf.

Donati, N. [2018]: MFF - Proposal for a stronger Europe? EuVisions. Centro di Ricerca e Documentazione Luigi Einaudi, University of Torino, Torino, http://www.euvisions.eu/ proposal-stronger-europe/.

EB [2010]: Európa 2020. Az intelligens, fenntartható és inkluzív növekedés stratégiája. Európai Bizottság, Brüsszel, COM(2010)2020 végleges. http://ec.europa.eu/eu2020/pdf/1_HU_ ACT_part1_v1.pdf.

EB [2013]: Ezermilliárd eurós beruházás Európa jövőjébe - az EU 2014-2020-as időszakra vonatkozó költségvetési kerete. IP-13-1096. Sajtóközlemény, november 19. Európai Bizottság, Brüsszel, http://europa.eu/rapid/press-release_IP-13-1096_hu.htm.

EB [2017a]: Fehér Könyv Európa jövőjéről. A 27 tagú EU útja 2025-ig: gondolatok és forgatókönyvek. COM(2017)2025., március 1. Európai Bizottság, Brüsszel, https://ec.europa.eu/ commission/sites/beta-political/files/feher_konyv_europa_jovojerol_hu.pdf. 
EB [2017b]: Vitaanyag az Európai Unió pénzügyeinek jövőjéről. COM(2017). No. 358. Európai Bizottság, Brüsszel, https://ec.europa.eu/commission/sites/beta-political/files/reflectionpaper-eu-finances_hu.pdf.

EB [2018a]: Modern költségvetés a polgárainak védelmet, biztonságot és lehetőségeket nyújtó Unió számára: Kérdések és válaszok. Európai Bizottság - Tájékoztató, május 2. MEMO/18/3621. Európai Bizottság, Brüsszel, http://europa.eu/rapid/press-release_MEMO18-3621_hu.htm.

EB [2018b]: Uniós költségvetés: a Bizottság modern költségvetést javasol egy olyan Unió számára, amely védelmet, biztonságot és lehetőségeket nyújt polgárainak. Európai Bizottság - Sajtóközlemény, május 2. IP No. 3570. Brüsszel, http://europa.eu/rapid/pressrelease_IP-18-3570_hu.pdf.

EB [2018c]: Modern költségvetés a polgárainak védelmet, biztonságot és lehetőségeket nyújtó Unió számára. A 2021-2027-es időszakra vonatkozó többéves pénzügyi keret. A Bizottság közleménye, $\operatorname{COM}(2018) 321$ final, május 2. Európai Bizottság, Brüsszel, https://eur-lex. europa.eu/legal-content/HU/TXT/HTML/?uri=CELEX:52018DC0321\&from=HU.

EC [2011]: Communication from the Commission to the European Parliament, the Council, the European Economic and Social Committee and the Committee of the Regions. A Budget for Europe 2020. Part I. European Commission, COM(2011) 500 final, június 29. Brüsszel, http://ec.europa.eu/budget/library/biblio/documents/fin_fwk1420/MFF_COM2011-500_Part_I_en.pdf.

EC [2013]: Multiannual Financial Framework 2014-2020. MFF in Figures. European Commission, Brüsszel, https://ec.europa.eu/info/about-european-commission/eu-budget/ documents/multiannual-financial-framework/2014-2020_en.

EC [2014]: EU budget 2013. Financial Report. Also covering Multiannual Financial Framework 2007-2013. European Commission Publications Office of the European Union, Luxembourg.

EC [2016]: Communication from the Commission to the European Parliament and the Council: Mid-term review/revision of the multiannual financial framework 2014-2020. An EU budget focused on results. $\operatorname{COM(2016)~} 603$ final, szeptember 14. European Commission, Brüsszel, http://ec.europa.eu/budget/mff/lib/COM-2016-603/COM2016-603_en.pdf.

EC [2017]: The Rome Declaration. Declaration of the Leaders of 27 Member States and of the European Council, the European Parliament and the European Commission, március 25. European Commission, Brüsszel, https://europa.eu/european-union/eu60_en.

EC [2018a]: Financing the EU budget: report on the operation of the own resources system. Accompanying the document Proposal of a Council Decision on the system of Own Resources of the European Union. Commission Staff Working Document, SWD(2018) 172 final, május 5. European Commission, Brüsszel, https://eur-lex.europa.eu/legal-content/ $\mathrm{EN} / \mathrm{TXT} /$ ?uri=CELEX\%3A52018SC0172.

EC [2018b]: A new, modern Multiannual Financial Framework for a European Union that delivers efficiently on its priorities post-2020. $\operatorname{COM(2018)~} 98$ final, február 14. European Commission, Brüsszel, https://ec.europa.eu/commission/sites/beta-political/files/ communication-new-modern-multiannual-financial-framework_en.pdf.

EC [2019]: EU expenditure and revenue 2014-2020. European Commission DG Budget, Brüsszel, http://ec.europa.eu/budget/graphs/revenue_expediture.html.

Enderlein, H. [2016]: Repair and Prepare: Growth and the Euro after Brexit. Bertelsmann Stiftung-Jacques Delors Institut, Berlin-Párizs, https://institutdelors.eu/wp-content/ uploads/2018/01/repair-and-prepare-growth-and-the-euro-after-brexit.pdf. 
EP [2018]: Confusing EU Budget figures: What are the real cuts and increases? Press Releases BUDG, május 23. European Parliament, Strasbourg, http://www.europarl.europa.eu/news/ en/press-room/20180523IPR04141/confusing-eu-budget-figures-what-are-the-real-cutsand-increases.

EP-CouncIL of EU-EC [1988]: Interinstitutional Agreement. L185. European ParliamentEuropean Council-European Commission, Official Journal, július 15.

EP-Council of EU-EC [1993]: Interinstitutional Agreement. European ParliamentEuropean Council-European Commission, Official Journal, C 331. november 22.

EP-Council of EU-EC [1999]: Interinstitutional Agreement 06.05.1999. European Parliament-European Council-European Commission, Official Journal, C 172. június 18. EP-EC-EC [2006]: Interinstitutional Agreement between the European Parliament, the Council and the Commission on budgetary discipline and sound financial management. European Parliament-European Council-European Commission, Official Journal, C 139. június 14. 1-10. o.

EU TANÁcsa [2013]: A Tanács 1311/2013/EU, Euratom-rendelete (2013. december 2.) a 20142020-as időszakra vonatkozó többéves pénzügyi keretről. Hivatalos Lap. L 347. december 20. 884-891. o. http://data.europa.eu/eli/reg/2013/1311/oj.

Figueria, F. [2009]: How to Reform the EU Budget? Methodological Toolkit. SIEPS Report, SIEPS, No. 5. http://discovery.ucl.ac.uk/1463295/1/MY\%20PAPERS\%20EU\%20Budget\%20 SIEPS\%20Report.pdf.

Fuest, C.-Heinemann, F.-Ungerer, M. [2015]: Reforming the Financing of the European Union: A Proposal. Intereconomics. Review of European Economic Policy, Vol. 50. No. 5. 288-293. o. https://doi.org/10.1007/s10272-015-0553-z.

Gros, D.-Micossi, S. [2005]: A Better Budget for the European Union. More Value for Money. More Money for Value. CEPS Policy Brief, No. 66. http://aei.pitt.edu/6585.

HaAs, J.-Rubio, E. [2017]: Brexit and the EU budget. Threat or opportunity? Policy Paper, No. 183. Jacques Delors Institut, Berlin, http://www.institutdelors.eu/media/brexiteubudgethaasrubio-jdi-jan17.pdf?pdf.

Haug, J.-Lamassoure, A.-Verhofstadt, G.-Gros, D.-De Grauwe, P.-Ricard-Nihoul, G.-Rubio, E. [2011]: Europe for Growth. For a Radical Change in Financing the EU. European Parliament-Center for European Policy Studies-Notre Europe, Brüsszel, http://ec.europa.eu/budget/mff/hlgor/library/selected-readings/07-DOC-COMMRadicalChangeFinancingEU-EPCEPSNotreEUROPE-2011.pdf.

Heinemann, F.-Mohl, Ph.-Osterloh, S. [2010]: Reforming the EU Budget: Reconciling Needs with Political-Economic Constraints. Journal of European Integration, Vol. 32. No. 1. 59-76. o. https://doi.org/10.1080/07036330903375149.

HÜBNER, D. [2017]: Regroup and Reform. Ideas for a more responsive and effective European Union. Report of a CEPS Task Force. Centre for European Policy Studies, Brüsszel, https:// www.ceps.eu/publications/regroup-and-reform-ideas-more-responsive-and-effectiveeuropean-union.

Juncker, J.-C. [2015]: The Five Presidents' Report: Completing Europe's Economic and Monetary Union. (Társszerző: Tusk, D.-Dijsselbloem, J.-Draghiand, M.-Schulz M.) European Commission, Brüsszel, https://ec.europa.eu/commission/publications/five-presidentsreport-completing-europes-economic-and-monetary-union_en.

Kengyel Ákos [2003]: Az EU költségvetésének feladatai és az arányos teherviselés. Külgazdaság, 47. évf. 4. sz. 65-77. o.

Kengyel Ákos [2007]: Az Európai Unió közös költségvetése kiadási oldalának 2014-től kívánatos szerkezete. Megjelent: Balázs Péter-Szemlér Tamás (szerk.): EU-költségvetés. Kihívások és reformtervek. MTA VKI-CEU ENS, Budapest, 106-162. o. 
Kengyel Ákos [2016]: New Headings - Old Problems: The Evolution and Future of the EU Budget. Intereconomics. Review of European Economic Policy, Vol. 51. No. 2. 100-106. o. https://doi.org/10.1007/s10272-016-0584-0.

Kengyel Áxos [2017]: The next Multiannual Financial Framework (MFF) and its duration. In-Depth Analysis requested by the BUDG committee. IP/D/BUDG/IC/2017_113. European Parliament, Directorate General for Internal Policies of the Union, Policy Department for Budgetary Affairs, Brüsszel, http://www.europarl.europa.eu/RegData/etudes/ IDAN/2017/603798/IPOL_IDA(2017)603798_EN.pdf.

Kengyel Ákos [2018]: A Neglected Aspect of the Debates on the EU Budget: Duration of the MFF. Intereconomics. Review of European Economic Policy, Vol. 53. No. 4. 225-232. o. https://doi.org/10.1007/s10272-018-0754-3.

Le Cacheux, J.-Laurent, E. [2009]: An ever less carbonated Union? Towards a better European taxation against climate change. Notre Europe, Studies and Research, No. 74. http://www.institutdelors.eu/wp-content/uploads/2018/01/europeantaxationclimatechan gelaurent-lecacheuxnenov09.pdf?pdf.

Matthews, A. [2018]: The CAP in the 2021-2027 MFF Negotiations. Intereconomics. Review of European Economic Policy, Vol. 53. No. 6. 306-311. o. https://doi.org/10.1007/s10272018-0773-0.

Monti, M. [2017]: Future Financing of the EU. Final report and recommendations of the High Level Group on Own Resources. European Commission, Brüsszel, december. http://ec.europa. eu/budget/mff/hlgor/library/reports-communication/hlgor-report_20170104.pdf.

Núñez-Ferrer, J.-Le Cacheux, J.-Benedetto, G.-Saunier, M. [2016]: Study on the Potential and Limitations of Reforming the Financing of the EU Budget. Június 3. Brüsszel, http://ec.europa.eu/budget/mff/hlgor/library/highlights/hlgor-studies-externalstudyonfinancingofeu-budget-june-2016_en.pdf.

PARry, M.-SAPAlA, M. [2018]: 2021-2027 multiannual financial framework and new own resources. Analysis of the Commission's proposal. PE 625.148. Július. European Parlamentary Research Service, Brüsszel, http://www.europarl.europa.eu/RegData/etudes/ IDAN/2018/625148/EPRS_IDA(2018)625148_EN.pdf.

Rubio, E. [2011]: The "added value" in EU budgetary debates: one concept, four meanings. Notre Europe Policy Brief, No. 28. http://institutdelors.eu/wp-content/uploads/2018/01/ bref28_addedvalue_en.pdf.

Schratzenstaller, M. [2018]: Tax-based Own Resources as a Core Element of a FutureOriented Design of the EU System of Own Resources. Intereconomics. Review of European Economic Policy, Vol. 53. No. 6. 301-306. o. https://doi.org/10.1007/s10272-018-0772-1.

TARschys, D. [2007]: Agenda 2014: A Zero-Base Approach. SIEPS European Policy Analysis, Issue 5-2007. SIEPS, Stockholm, http://www.sieps.se/en/publications/european-policyanalysis/-agenda-2014-a-zero-base-approach-20075epa.html. 